\title{
Review
}

\section{Yttrium Oxide Nanoparticle Synthesis: An Overview of Methods of Preparation and Biomedical Applications}

\author{
Govindasamy Rajakumar ${ }^{1}{ }^{\circledR}$, Lebao Mao ${ }^{1}$, Ting Bao ${ }^{1}$, Wei Wen ${ }^{1}$, Shengfu Wang ${ }^{1}$, Thandapani Gomathi ${ }^{2}{ }^{\oplus}$, \\ Nirmala Gnanasundaram ${ }^{3}{ }^{(0)}$, Maksim Rebezov ${ }^{4,5}{ }^{1}$, Mohammad Ali Shariati ${ }^{6} \mathbb{D}^{\circ}$, Ill-Min Chung ${ }^{7}$, \\ Muthu Thiruvengadam ${ }^{7, *}$ and Xiuhua Zhang ${ }^{1, *}$
}

1 Collaborative Innovation Center for Advanced Organic Chemical Materials Co-Constructed by the Province and Ministry, Ministry-of-Education Key Laboratory for the Synthesis and Application of Organic Functional Molecules and College of Chemistry and Chemical Engineering, Hubei University, Wuhan 430062, China; microlabsraj@gmail.com (G.R.); shadowlordr7@gmail.com (L.M.); rajagkorea@gmail.com (T.B.); lakhith14@gmail.com (W.W.); rengasenthil76@gmail.com (S.W.)

2 Department of Chemistry, D.K.M. College for Women, Vellore 632001, Tamil Nadu, India; chemist.goms@gmail.com

3 Mass Transfer Lab, School of Chemical Engineering, VIT University, Vellore 632014, Tamil Nadu, India; gsnirmala@vit.ac.in

4 V.M. Gorbatov Federal Research Center for Food Systems of Russian Academy of Sciences, 26 Talalikhina St., 109316 Moscow, Russia; rebezov@yandex.ru

5 Prokhorov General Physics Institute of the Russian Academy of Science, 38 Vavilova Str., 119991 Moscow, Russia

6 Department of Technology of Food Products, K.G. Razumovsky Moscow State University of Technologies and Management (The First Cossack University), 73, Zemlyanoy Val St., 109004 Moscow, Russia; shariatymohammadali@gmail.com

Citation: Rajakumar, G.; Mao, L.; Bao, T.; Wen, W.; Wang, S.; Gomathi, T.; Gnanasundaram, N.; Rebezov, M.; Shariati, M.A.; Chung, I.-M.; et al. Yttrium Oxide Nanoparticle Synthesis: An Overview of Methods of Preparation and Biomedical Applications. Appl. Sci. 2021, 11, 2172. https://doi.org/10.3390/app 11052172

Received: 3 December 2020 Accepted: 22 February 2021 Published: 2 March 2021

Publisher's Note: MDPI stays neutral with regard to jurisdictional claims in published maps and institutional affiliations.

Copyright: (c) 2021 by the authors. Licensee MDPI, Basel, Switzerland. This article is an open access article distributed under the terms and conditions of the Creative Commons Attribution (CC BY) license (https:// creativecommons.org/licenses/by/ $4.0 /)$.
Department of Crop Science, College of Sanghuh Life Science, Konkuk University, Seoul 05029, Korea; imcim@konkuk.ac.kr

* Correspondence: muthu@konkuk.ac.kr (M.T.); zhangxh@hubu.edu.cn (X.Z.)

Abstract: Metal oxide nanoparticles demonstrate uniqueness in various technical applications due to their suitable physiochemical properties. In particular, yttrium oxide $\left(\mathrm{Y}_{2} \mathrm{O}_{3}\right)$ nanoparticle is familiar for technical applications because of its higher dielectric constant and thermal stability. It is widely used as a host material for a variety of rare-earth dopants, biological imaging, and photodynamic therapies. $\mathrm{Y}_{2} \mathrm{O}_{3}$ has also been used as a polarizer, phosphor, laser host material, and in the optoelectronic fields for cancer therapy, biosensor, and bioimaging. Yttrium oxide nanoparticles have attractive antibacterial and antioxidant properties. This review focuses on the promising applications of $\mathrm{Y}_{2} \mathrm{O}_{3}$, its drawbacks, and its modifications. The synthetic methods of nanoparticles, such as sol-gel, emulsion, chemical methods, solid-state reactions, combustion, colloid reaction techniques, and hydrothermal processing, are recapitulated. Herein, we also discuss the advantages and disadvantages of $\mathrm{Y}_{2} \mathrm{O}_{3}$ NPs based biosensors that function through various detection modes including colorimetric, electrochemistry, and chemo luminescent regarding the detection of small organic chemicals, metal ions, and biomarkers.

Keywords: yttrium oxide; rare earth metals; synthesis; drug delivery; biomedical; applications

\section{Introduction}

In recent times, rare earth metal nanomaterials are the more popular and commonly used material for its device applications and are synthesized in the form of nanoparticles (NPs), nanotubes, rods, and sheets. Metal nanoparticles have been developed that are comprised of various metals, magnetic, metal oxides, and quantum dots [1], while organic nanoparticles include liposomes, dendrimers, albumin-coated NPs, polymeric NPs, and lipid NPs [2]. In this review, we address yttrium oxide $\left(\mathrm{Y}_{2} \mathrm{O}_{3}\right)$, an inorganic nanoparticle which is one kind of precious rare earth element. Recently, a geological survey of the 
United States [3] has emphasized that the estimated yttrium was $0.12 \%$ among rare earth elements, and demonstrated the end-use of yttrium in ceramic, metallurgy, and phosphors. The majority of world production of yttrium oxide in 2018 was from China, and was estimated to be 7000 tons. The leading countries of yttrium reserves include Australia, Canada, China, and India. $\mathrm{Y}_{2} \mathrm{O}_{3}$ is used as a component in uranium-resistant refractory ceramic, liquid reactive molten alloys and salts within the frame of atomic reactors $[4,5]$, and it makes a superb defensive coating, as well as another suitable choice for silicon dioxide in metal-oxide-semiconductor devices. It is widely used in the ceramic field as abrasives and seals with high-temperature tolerability. It is also used in jet engine coating and used as an oxygen sensor in automobiles, It is corrosion-resistant to cutting tools [6,7]. In metallurgy, it is used as a grain-refining additive and deoxidizer, as a superior temperature conductor, and as the best alloys. The yttrium derivatives were used in electronic applications of microwave radar, digital communications, temperature sensors, nonlinear optics, photochemistry, and photoluminescence. Yttrium has played a vital part in yttrium aluminum garnet laser crystals that are applied in surgical procedures in medical and dentistry.

Many researchers report the properties of $\mathrm{Y}_{2} \mathrm{O}_{3}$ as being chemically stable, having a higher degree of hardness, and possessing unique optoelectronic properties [8-10], and the applications as solar energy processes [11], lithium-ion batteries [12,13], and components for rare-earth-doped lasers $[14,15]$ found that the composite of carbon nanotubes (CNTs) and $\mathrm{Y}_{2} \mathrm{O}_{3}$ can be used to detect acetaminophen with good electrocatalytic activity. As rare earth nanomaterials, $\mathrm{Y}_{2} \mathrm{O}_{3}$ nanoparticles have an attractive high refractive index, large bandgap (5.8 eV), high dielectric constant, and high warm stability region [16], which is the essential criteria for photodynamic therapy [17], biological imaging [18], luminescence [19], and nuclear power systems [20]. $\mathrm{Y}_{2} \mathrm{O}_{3}$ nanoparticles have been synthesized as nanorods and nanoflakes with controlled morphology via hydrothermal synthesis by varying $\mathrm{pH}$, with lengths and lateral dimensions of the order of microns [21]. Deng et al. [22] illustrated how $\mathrm{Y}_{2} \mathrm{O}_{3}$ influences the mechanical properties of calcium phosphate coated on Ti6Al4V, a promising bio-ceramic fabric. $\mathrm{Y}_{2} \mathrm{O}_{3}$ as highly efficient and functional composite materials was applied as yttria-stabilized zirconia films [23,24].

In the biomedical field, NPs exhibited diverse applications, such as drug delivery systems, gene therapy, the discovery of pathogens, and identification of proteins and tissues. However, its involvement in DNA-related research was also reported, such as the purification process, DNA separation and structure, and tumor inhibition techniques [25]. Nanosized particles have shown to achieve a better outcome in the wastewater management system, owing to its extended surface area to volume ratio, and assistance in the purification of the water treatment process [26]. Metal oxides NPs are used as water treatment catalysts [27,28]. In cosmetics, raw materials of solar cells have been reported [29]. Metal oxides nanoparticles, covering zinc oxide, titanium, cerium, and yttrium oxide NPs, have been extensively studied. Each nanoparticle has been shown to have unique features. The current study shows that $\mathrm{Y}_{2} \mathrm{O}_{3}$ with rare-earth ions doped can also be used for solidstate lighting purposes [30]. $\mathrm{Y}_{2} \mathrm{O}_{3}$ with a maximum of $9.71 \%$ rare earth is used in LEDs. The first demonstration of a high-spatial-resolution and multicolor imaging technique for observation of biological cells using cathodoluminescence (CL) from nanophosphors has been observed. CL is emission from materials irradiated by the accelerated electron beam. For CL imaging, $\mathrm{Y}_{2} \mathrm{O}_{3}: T m, \mathrm{Y}_{2} \mathrm{O}_{3}: \mathrm{Tb}, \mathrm{Y}_{2} \mathrm{O}_{3}$ :Eu were used as the phosphors. The spectral bandwidth of the phosphors was narrow enough to distinguish the types of the phosphors. Yttrium oxide doped with europium $\left(\mathrm{Y}_{2} \mathrm{O}_{3}: \mathrm{Eu}\right)$ is a luminescent material with red-orange emission, excitation by electrons (cathodoluminescence). Rare-earth doped ceramic materials show efficient fluorescence under near-infrared (NIR) excitation. Current investigation shows that $\mathrm{Y}_{2} \mathrm{O}_{3}$ :Er particles and the surface modification of these particles with double layers of PAAc (acrylic acid) as an interfacing agent and acetal-PEG-b-PAMA led to successful NIR imaging nanoparticles. Grain size of these particles is found to be $10 \mathrm{~nm}$ to $200 \mathrm{~nm}$, which are found to be good for near-infrared excitation. Among the 
mentioned, yttrium oxide NPs have shown to be the priority of several research efforts, which is attributable to their unmatched number of applications in diverse fields, including biomedicine. However, the available published resources on the $\mathrm{Y}_{2} \mathrm{O}_{3}$ synthesis methods and its emerging biomedical applications are very scarce. Hence, the present review article highlights the methods of $\mathrm{Y}_{2} \mathrm{O}_{3}$ synthesis and mode of action and discusses their biomedical applications in some detail.

\section{Synthesis of Yttrium}

Several methods have been employed for the preparation of yttrium oxide. It is noteworthy that while the schemes and approaches of synthesis are similar, the properties, such as physiochemical, depended upon the particle's potentials. Therefore, in the first section of this review, we present the advanced methods of the synthesis of $\mathrm{Y}_{2} \mathrm{O}_{3}$ with its various applications (Table 1). Prolonged-time synthesis of $\mathrm{Y}_{2} \mathrm{O}_{3}$ has proved attractive in recent times for many cancer-related purposes, which have evolved chiefly due to the nanoparticle's excellent and appealing physicochemical properties [31]. Various physical and chemical synthesis processes have been practiced for fabricating $\mathrm{Y}_{2} \mathrm{O}_{3}$ nanoparticles, such as the sol-gel method, hydrothermal, green synthesis, precipitation method, citrate precipitation method, acid composition mediation method, and mycoplasma-assisted method.

Table 1. Different methods and applications of synthesized yttrium oxide nanoparticles $\left(\mathrm{Y}_{2} \mathrm{O}_{3}\right)$.

\begin{tabular}{|c|c|c|c|c|}
\hline$\#$ & Method & Application & Precursor & Ref. \\
\hline 1 & $\begin{array}{l}\text { Synthesis of up-converting } \\
\text { nanoparticles acid } \\
\text { composition method }\end{array}$ & $\begin{array}{c}\text { To improve infrared light conversion } \\
\text { to visible light in optoelectronic } \\
\text { devices }\end{array}$ & $\begin{array}{l}\text { Yttrium and europium oxides with } \\
\text { acetic acid are }+\mathrm{HNO}_{3}+\mathrm{HCl} \text { using } \\
\text { hydrothermal microwave irradiation }\end{array}$ & [32] \\
\hline 2 & $\begin{array}{l}\text { Microplasma-assisted } \\
\text { method }\end{array}$ & $\begin{array}{c}\text { Used in optical emission, emission } \\
\text { spectroscopic studies, plasma kinetic } \\
\text { analysis }\end{array}$ & Yttrium nitrate with water medium & [33] \\
\hline 3 & Hydrothermal method & $\begin{array}{l}\text { Improves the efficiency of light to } \\
\text { electric transformation by converting } \\
\text { UV light to visible light. One half of } \\
\mathrm{Y}_{2} \mathrm{O}_{3} \text { enhances open circuit voltage }\end{array}$ & $\mathrm{TiO}_{2}$ on dye-sensitized solar cells & [34] \\
\hline 4 & $\begin{array}{l}\text { Hydrothermal method } \\
\text { (synthesis of nanorod) }\end{array}$ & $\begin{array}{l}\text { Enhance infrared light harvest and } \\
\text { increase photocurrent or } \\
\text { dye-sensitized solar cells (DSSC) }\end{array}$ & $\frac{1}{2} \mathrm{Y}_{2} \mathrm{O}_{3}: \mathrm{Er}^{3}$ & [30] \\
\hline \multirow{3}{*}{5} & \multirow{3}{*}{ Sol-gel process } & $\begin{array}{l}\text { Ethylene tetraacetic acid (EDTA) } \\
\text { complexing sol-gel process particle is } \\
\text { fine and requires no further grinding }\end{array}$ & Metal nitrate and EDTA & [35] \\
\hline & & $\begin{array}{l}\text { Antioxidant property used in a } \\
\text { biological system }\end{array}$ & $\begin{array}{l}\text { Yttrium nitrate yttrium chlorate in } \\
\text { methanol with } \mathrm{P}-123 \text { poloxamer }\end{array}$ & [36] \\
\hline & & $\begin{array}{l}\text { i. Auto catalytic-polymerization } \\
\text { ii. Sol-gel method: Adjusting of } \\
\text { electrochemical criteria } \\
\text { iii. Cytotoxicity effect through human } \\
\text { neuroblastoma cell. }\end{array}$ & $\begin{array}{l}\text { i. Hexahydrate yttrium chlorite } \\
\text { ii. Yttrium hydroxide } \\
\text { iii. Yttrium chloride }\left(\mathrm{YCl}_{3} \cdot 6 \mathrm{H}_{2} \mathrm{O}\right)\end{array}$ & [37] \\
\hline 6 & $\begin{array}{l}\text { i. Cathodic electrodeposition } \\
\text { method } \\
\text { ii. Thermal decomposition }\end{array}$ & $\begin{array}{l}\text { i. Crystalline size }(40-60) \mathrm{nm} \\
\text { ii. Thermal decomposition particle } \\
\text { size } 30 \mathrm{~nm}\end{array}$ & Yttrium hydroxide & [8] \\
\hline 7 & $\begin{array}{l}\text { Citrate precipitate on the } \\
\text { method (Surfactant PEG } \\
\text { 2000) using azeotropic } \\
\text { distillation }\end{array}$ & $\begin{array}{l}\text { Torispherical and uniform-sized } \\
\text { Particle with a developed structure }\end{array}$ & Yttrium chlorate $\left(\mathrm{YCL}_{3}\right)$ & [9] \\
\hline
\end{tabular}


Table 1. Cont.

\begin{tabular}{cccc}
\hline$\#$ & Method & Application & Precursor \\
\hline 8 & $\begin{array}{c}\text { Biosynthesis from Acalypha } \\
\text { indica leaf extract size }(23 \mu \mathrm{m} \\
\text { to } 66 \mathrm{~nm})\end{array}$ & $\begin{array}{c}\text { Increasing the rate of antibacterial } \\
\text { behavior }\end{array}$ & $\begin{array}{c}\text { Yttrium nitrate hexahydrate }+ \text { A. } \\
\text { indica leaf }\end{array}$ \\
\hline 9 & $\begin{array}{c}\text { Yttrium oxide in the } \\
\text { microwave field }\end{array}$ & Yttrium oxalate hydrate & $\begin{array}{c}\text { Narrow particle size distribution, used } \\
\text { for industrial processing }\end{array}$ \\
\hline 10 & Green method synthesis & $\begin{array}{c}\text { Efficient anticancer activity against } \\
\text { renal cancer }\end{array}$ & Plant-based \\
\hline 11 & $\begin{array}{c}\text { Sono-chemical irradiation } \\
\text { method }\end{array}$ & Antimicrobial, anti-biofilm production & Yttrium III acetate tetrahydrate \\
\hline 12 & $\begin{array}{c}\text { Chemical precipitation } \\
\text { method }\end{array}$ & Transparent ceramic & Carbonate yttrium + nitric acid \\
\hline
\end{tabular}

\subsection{Hydrothermal Process}

According to wet chemistry methods, the hydrolysis of yttrium salt solutions can be scaled up. The lower solubility of $\mathrm{Y}(\mathrm{OH})_{3}(\mathrm{Ks} \sim(10-22.1))$ is highly challenging during the synthesis of $\mathrm{Y}_{2} \mathrm{O}_{3}$ nanoparticles in hydrothermal processes with uniform nuclei sizes and growth [42]. $\mathrm{Y}_{2} \mathrm{O}_{3}$ nanocubes were synthesized using Hexamethylenetetramine (HMTA) and $\mathrm{YCl}_{3}$ solutions (required amount dissolved in $60 \mathrm{~mL}$ of deionized water). The mixture was stirred for $1 \mathrm{~min}$, and then transferred to a $100 \mathrm{~mL}$ Teflon-lined autoclave for heating at $180^{\circ} \mathrm{C}$ for $24 \mathrm{~h}$. After $24 \mathrm{~h}$, the obtained products were cooled to room temperature (RT), washed, and dried at $50^{\circ} \mathrm{C}$ for $24 \mathrm{~h}$ (Table 2).

Table 2. Synthesis of yttrium oxide by hydrothermal method.

\begin{tabular}{|c|c|c|c|c|c|}
\hline \# & Precursors & Medium & Temperature & Obtained & Ref. \\
\hline 1 & Yttrium salts, ammonia, water & Chloride, nitrate & $\begin{array}{l}(200-270)^{\circ} \mathrm{C} \\
((0-120) \min )\end{array}$ & Yttrium grains & [43] \\
\hline 2 & $\begin{array}{c}\mathrm{Y}\left(\mathrm{NO}_{3}\right)_{3} \cdot 6 \mathrm{H}_{2} \mathrm{O}(3.83 \mathrm{~g}) \text {, and } \\
\text { urea }(0.5 \mathrm{~g})\end{array}$ & water & $140^{\circ} \mathrm{C}$ for $12 \mathrm{~h}$ & $\mathrm{Y}(\mathrm{OH}) \mathrm{CO}_{3}$ & [44] \\
\hline 3 & $\begin{array}{l}\mathrm{Y}\left(\mathrm{NO}_{3}\right)_{3} 6 \mathrm{H}_{2} \mathrm{O}, \\
\text { Glycine, water, }\end{array}$ & $\mathrm{NH}_{3} \cdot \mathrm{H}_{2} \mathrm{O}$ & $170{ }^{\circ} \mathrm{C}$ for 5 days & $\begin{array}{l}\mathrm{Y}(\mathrm{OH})_{3} \\
\text { nest-like }\end{array}$ & [45] \\
\hline 4 & $\mathrm{Y}_{2} \mathrm{O}_{3}$, nitric acid & $\begin{array}{l}\text { ammonia } \\
\text { (or) } \mathrm{NaOH}\end{array}$ & $(80-220){ }^{\circ} \mathrm{C}$ for $24 \mathrm{~h}$ & Hexagonal $\mathrm{Y}(\mathrm{OH})_{3}$ & [46] \\
\hline 5 & $\begin{array}{c}\text { Pure } \mathrm{Y}_{2} \mathrm{O}_{3} \text { was dissolved in } \\
\text { an } \mathrm{HNO}_{3} \text { solution }\end{array}$ & $\mathrm{NaOH}$ solution & $110^{\circ} \mathrm{C}$ for $72 \mathrm{~h}$ & $\mathrm{Y}_{2} \mathrm{O}_{3}$ nanotubes (NTs) & [47] \\
\hline 6 & Pure $\mathrm{Y}_{2} \mathrm{O}_{3}$ & $\mathrm{NaOH}$ solution & $150^{\circ} \mathrm{C}$ for $12 \mathrm{~h}$ & $\begin{array}{c}\text { Hexagonal } \mathrm{Y}(\mathrm{OH})_{3} \text { with } \\
\text { nanotube and microrod } \\
\text { morphologies }\end{array}$ & [13] \\
\hline 7 & $\begin{array}{c}\mathrm{Y}\left(\mathrm{NO}_{3}\right)_{3} \cdot 8 \mathrm{H}_{2} \mathrm{O}, 0.5 \mathrm{~g} \\
\text { PEG-6000 and } 20 \mathrm{~mL} \text { water }\end{array}$ & $\mathrm{NaOH}$ & $60^{\circ} \mathrm{C}$ for $4 \mathrm{~h}$ & $\begin{array}{c}\mathrm{Y}(\mathrm{OH})_{3} \text { and } \mathrm{Y}_{2} \mathrm{O}_{3} \\
\text { nanotubes }\end{array}$ & [48] \\
\hline 8 & $\begin{array}{l}\text { hydrate yttrium nitrate and } \\
\text { methyl salicylate }\end{array}$ & ethyl acetate & $80^{\circ} \mathrm{C}$ for $120 \mathrm{~min}$ & Porous cubic yttrium oxides & [49] \\
\hline
\end{tabular}

$\mathrm{Y}_{2} \mathrm{O}_{3}$ nanoparticles in the shape of flowers can be synthesized using HMTA, $\mathrm{YCl}_{3}$, and phenol solutions (all dissolved in $60 \mathrm{~mL}$ of deionized water). The same procedure was followed for the synthesis of $\mathrm{Y}_{2} \mathrm{O}_{3}$ flowers as $\mathrm{Y}_{2} \mathrm{O}_{3}$ cubes, as shown in Figure 1, to form the composite $\mathrm{Y}_{2} \mathrm{O}_{3}$ plate/phenolic resin structures. The phenolic resin is formed during the reaction between phenol and formaldehyde, which is the product of the reaction between HMTA and deionized water. Subsequently, the composite $\mathrm{Y}_{2} \mathrm{O}_{3} /$ phenolic resin 
structures were further annealed at $600{ }^{\circ} \mathrm{C}$ for $8 \mathrm{~h}$ to remove the phenolic-resin template, which resulted in the formation of $\mathrm{Y}_{2} \mathrm{O}_{3}$ flowers [50].

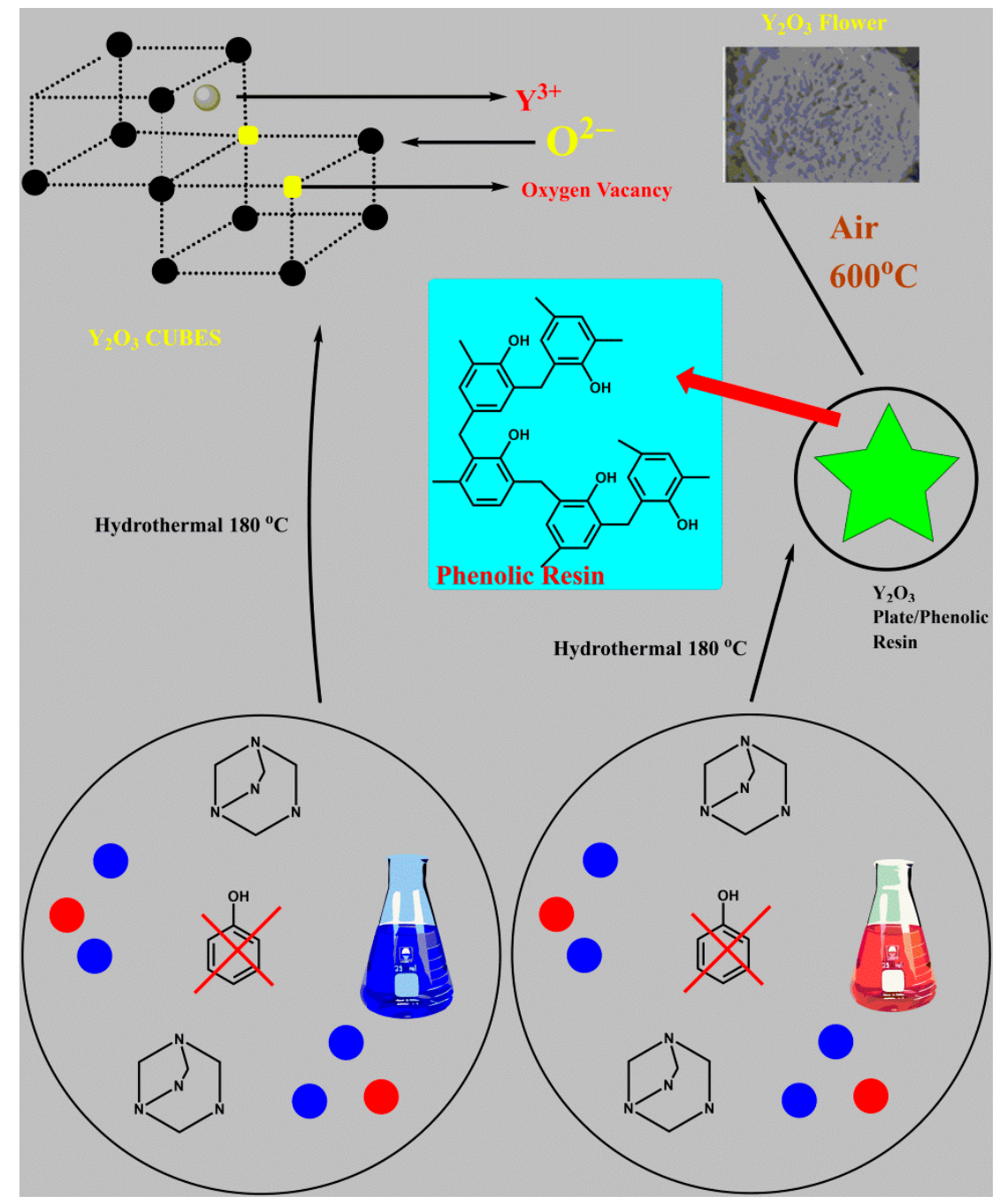

Figure 1. Scheme for the preparation of $\mathrm{Y}_{2} \mathrm{O}_{3}$ cubes and flowers [50].

\subsection{Precipitation Method}

Due to the perspective applications and properties of $\mathrm{Y}_{2} \mathrm{O}_{3}$, the preparation of $\mathrm{Y}_{2} \mathrm{O}_{3}$ has emerged as a widely increasing trend. However, a series of preparation methods have been reported in a few decades - these include precipitation [51] and sol-gel practice [52]. Precipitation is a popularly used technique, and is simple for the synthesis of $\mathrm{Y}_{2} \mathrm{O}_{3} \mathrm{NPs}$ (Table 3) and yttria powder for large-scale industrial production with low cost to regulate the size of particles. $\mathrm{Y}_{2} \mathrm{O}_{3}$ NPs can be synthesized using a simple co-precipitation method in a distillate pack, followed by calcination of the precursor, yttrium oxalate $\left(\mathrm{Y}_{2}\left(\mathrm{C}_{2} \mathrm{O}_{4}\right)_{3}\right)$ in a furnace with the reaction varied between room temperature (RT) and $100{ }^{\circ} \mathrm{C}$ for various reaction durations ranging $(0.5$ to 3$) \mathrm{h}$. The results proved that pure $\mathrm{Y}_{2} \mathrm{O}_{3}$ was synthesized using the processing parameters, which were in good agreement with the thermogravimetric analysis (TGA), X-ray diffraction (XRD), and Raman analysis results for co-precipitation reaction at $40^{\circ} \mathrm{C}$ for $1 \mathrm{~h}$, followed by calcination at $650{ }^{\circ} \mathrm{C}$ for $4 \mathrm{~h}$. This method yielded semispherical $\mathrm{Y}_{2} \mathrm{O}_{3}$ nanoparticles with crystallite sizes ranging (7-21) nm, and a large specific surface area of $7.40 \mathrm{~m}^{2} / \mathrm{g}$ [53].

Bhavani and Ganesan et al. [54] synthesized this familiar yttrium compound and doped it with bismuth and zinc oxide, as they have been shown to have an extended bandgap, and tested their optical properties. As a result, the wet chemical method is 
prompt and easy to synthesize $\mathrm{Bi}$ and $\mathrm{Zn}$ co-doped yttrium oxide nanoparticles for various phosphor utilities. Another study conducted by Su et al. [55] revealed that $\mathrm{Y}_{2} \mathrm{O}_{3}$ stability could be improved, and appreciable absorption selectivity was achieved by adding $\mathrm{ZnO}_{3}$ to form $\mathrm{Y}_{2} \mathrm{O}_{3} \mathrm{ZnO}$ complex using the precipitation method. The complexes proved to be acting as a photocatalyst.

Table 3. Synthesis of yttrium oxide by the precipitation method.

\begin{tabular}{|c|c|c|c|c|}
\hline \# & Precursors & Medium & Methods & Ref. \\
\hline 1 & Yttrium, europium, chloride salts, HCL & Ammonia & Co-precipitation & [57] \\
\hline 2 & $\begin{array}{l}\text { Yttrium nitrate, hafnium (IV) chloride, diammonium oxalate } \\
\text { monohydrate, polyethylene glycol } 6000\end{array}$ & Water & Co-precipitation & [56] \\
\hline 3 & Yttrium nitrate hexahydrate, $\mathrm{Na}_{2} \mathrm{CO}_{3}, \mathrm{KOH}$, and $\mathrm{NaOH}$ & Water & Co-precipitation & [58] \\
\hline 4 & $\begin{array}{l}\text { Yttrium nitrate, nitric acid, ammonia } \\
\text { and ammonium, hydro-carbonate }\end{array}$ & Water, alcohol & Precipitation & [41] \\
\hline 5 & Yttria powder, nitric acid, ammonia sulfate & Ammonia water & Precipitation & [59] \\
\hline 6 & yttrium nitrate and urea & Water & Precipitation & [60] \\
\hline 7 & Yttria, nitric acid, aluminum nitrate, urea & Water & Precipitation & [61] \\
\hline 8 & $\mathrm{Y}_{2} \mathrm{O}_{3}(95 \mathrm{~mol} . \%)$ and $\mathrm{Eu}_{2} \mathrm{O}_{3}(5 \mathrm{~mol} . \%)$ were dissolved in $\mathrm{HNO}_{3}$, & Water & Precipitation & [62] \\
\hline 9 & $\mathrm{Y}_{2} \mathrm{O}_{3}(95 \mathrm{~mol} . \%)$ and $\mathrm{Eu}_{2} \mathrm{O}_{3}(5 \mathrm{~mol} . \%)$ were dissolved in $\mathrm{AcOH}$ & Ethylene glycol (EG), & Precipitation & [62] \\
\hline 10 & $\mathrm{Y}\left(\mathrm{NO}_{3}\right)_{3}(77 \mathrm{~mL}), \mathrm{Yb}\left(\mathrm{NO}_{3}\right)_{3}(20 \mathrm{~mL}), \mathrm{Er}\left(\mathrm{NO}_{3}\right)_{3}$ & EDTA & Precipitation & [63] \\
\hline 11 & $\left(\mathrm{Y}(\mathrm{NO})_{3} \cdot 6 \mathrm{H}_{2} \mathrm{O}\right), \mathrm{Na}_{2} \mathrm{CO}_{3}, \mathrm{KOH}$ and $\mathrm{NaOH}$ & Ammonium hydroxide & Co-precipitation & [58] \\
\hline
\end{tabular}

Yttrium hafnate $\left(\mathrm{Y}_{2} \mathrm{Hf}_{2} \mathrm{O}_{7}\right)$ precursor was prepared by mixing yttrium nitrate and hafnium (IV) chloride with ammonium oxalate aqueous solution using the oxalate coprecipitation method at $800{ }^{\circ} \mathrm{C}$ for $4 \mathrm{~h}$. Platelet, rod, and spherical shape $\mathrm{Y}_{2} \mathrm{Hf}_{2} \mathrm{O}_{7}$ powders were obtained by controlling the concentration of the surfactant PEG6000, and it played a vital role in the morphology of the particles [56]. Huang et al. [41] synthesized yttria nanopowders with a narrow size distribution using a precipitation method. In this process, the $\mathrm{pH}$ value at the end has a significant effect on the size and morphology of the precursor and the yttria powders; under the same calcination condition, the yttria powders made from the precursor obtained at a $\mathrm{pH}$ of 8 are smaller in mean particle size and narrower in size distribution than those made from the precursor obtained at a $\mathrm{pH}$ of 10 with the optimum calcination temperature of $1000{ }^{\circ} \mathrm{C}$. The nanopowder was obtained at $30 \mathrm{~nm}$ size and was well dispersed. Using this yttria nanopowder, transparent yttria ceramics were produced by vacuum sintering at $1700^{\circ} \mathrm{C}$ for $4 \mathrm{~h}$ without any additives.

\subsection{The Sol-Gel Method}

The Sol-gel method of yttrium preparation is a preferable technique used by several researchers. In this method, yttrium nitrate and yttrium chloride were used as precursors with methanol. To accelerate oxygen gaps, maP-123 Poloxamer can be inserted [36]. The manufacturing set-up was heating at 700 and $900{ }^{\circ} \mathrm{C}$ with various molar ratios of $(1: 1$ and 1:2). The characteristic absorption bond of $\mathrm{Y}-\mathrm{O}$ vibration was shown to be the same as $\mathrm{Y}_{2} \mathrm{O}_{3}$ matrix. XRD can analyze the structural phase. The crystalline obtained was determined by the Scherrer equation within the range (21 to 32) nm. $\mathrm{Y}_{2} \mathrm{O}_{3}$ using the sol-gel method was reported by Mariano-Torres et al. [37]. In their experiment, a hybrid polymer glycol citrate polymer, glycerol citrate polymer (GCP), and $\mathrm{Y}_{2} \mathrm{O}_{3}$ nanoparticles were synthesized. The antibacterial ability of citrate-based polymer nanoparticles is reportedly involved in biomedical applications, as citrate has been from a natural source. In 2003, Zhai et al. [35] synthesized $\mathrm{Y}_{2} \mathrm{O}_{3}$ Eu-doped nanopowder using ethylene tetraacetic acid (EDTA) complex with a comparatively low temperature of $600-100{ }^{\circ} \mathrm{C}$ and using metal nitrate as precursors. EDTA and polyethylene glycol were acting as a chelating factor and polymerization activators, and from the mentioned solution system, $\mathrm{Y}_{2} \mathrm{O}_{3}$ Eu nanopowder was extracted. EDTA was reported to be the best chelator to the cations and offered stable complex with good solubility. All materials with precursors were blended on a molecular basis in a solution, which helps regulate the composition and homogeneity. During the polymerization reac- 
tion, EDTA-stimulated PEG can provide an excellent suppressing cation assemblage, and homogenous gel $\mathrm{Y}_{2} \mathrm{O}_{3}$ : EU nanopowder with purity can be obtained. Particles seem to be spherical. It required no further milling or grinding. In addition, Bhagat et al. [64] have postulated that $\mathrm{Y}_{2} \mathrm{O}_{3}$ acts as a catalyst for the synthesis of pyrimidine in methanol media. $\mathrm{Y}_{2} \mathrm{O}_{3}$ powders had been successfully synthesized through the sol-gel process using glycerol and polyethylene glycol as additives accompanied through low-temperature $\left(550^{\circ} \mathrm{C}\right)$ annealing, and the results show an intense bluish-white emission with a quantum yield as high as 64.6\% under a wide range of UV-light excitation of (235-400) $\mathrm{nm}$ [65].

Although the Pechini technique [66] (a variation of the sol-gel method) is an inexpensive and convenient way to prepare rare earth ion (REI)-doped phosphors, it results in the formation of strongly agglomerated nanocrystalline powders [67-69]. A novel synthesized nanocrystalline Eu ${ }^{3+}$-doped $\mathrm{Y}_{2} \mathrm{O}_{3}$ materials combined Pechini-foaming technique. Analytically detectable amounts of defect sites were reached in $\mathrm{Y}_{2} \mathrm{O}_{3}$, synthesized $\mathrm{Eu}^{3+}$ nanopowders with an average size of $40-50 \mathrm{~nm}$. It was found that the increasing $\mathrm{Eu}^{3+}$ doping concentration leads to the redshift of Raman lines. The intense emissions of the nanophosphors due to doping with the $\mathrm{Eu}^{3+}$ ions are assigned to transitions occurring between the 5D0 excited state and 7FJ ground states of these ions. Most efficient emissions were activated by charge transfer between $\mathrm{Eu}^{3+}$ and $\mathrm{O}^{2-}$, and subsequent energy transfer to the dopant ions. The outcomes of this research are that $\mathrm{Eu}^{3+}$ ions could occupy not only two well-known symmetry sites in cubic $\mathrm{Y}_{2} \mathrm{O}_{3}$ host $\mathrm{C}_{2}$ (non-centrosymmetric) and $\mathrm{C} 3 \mathrm{i}$ (centrosymmetric), but also defect sites (Figure 2) [70].

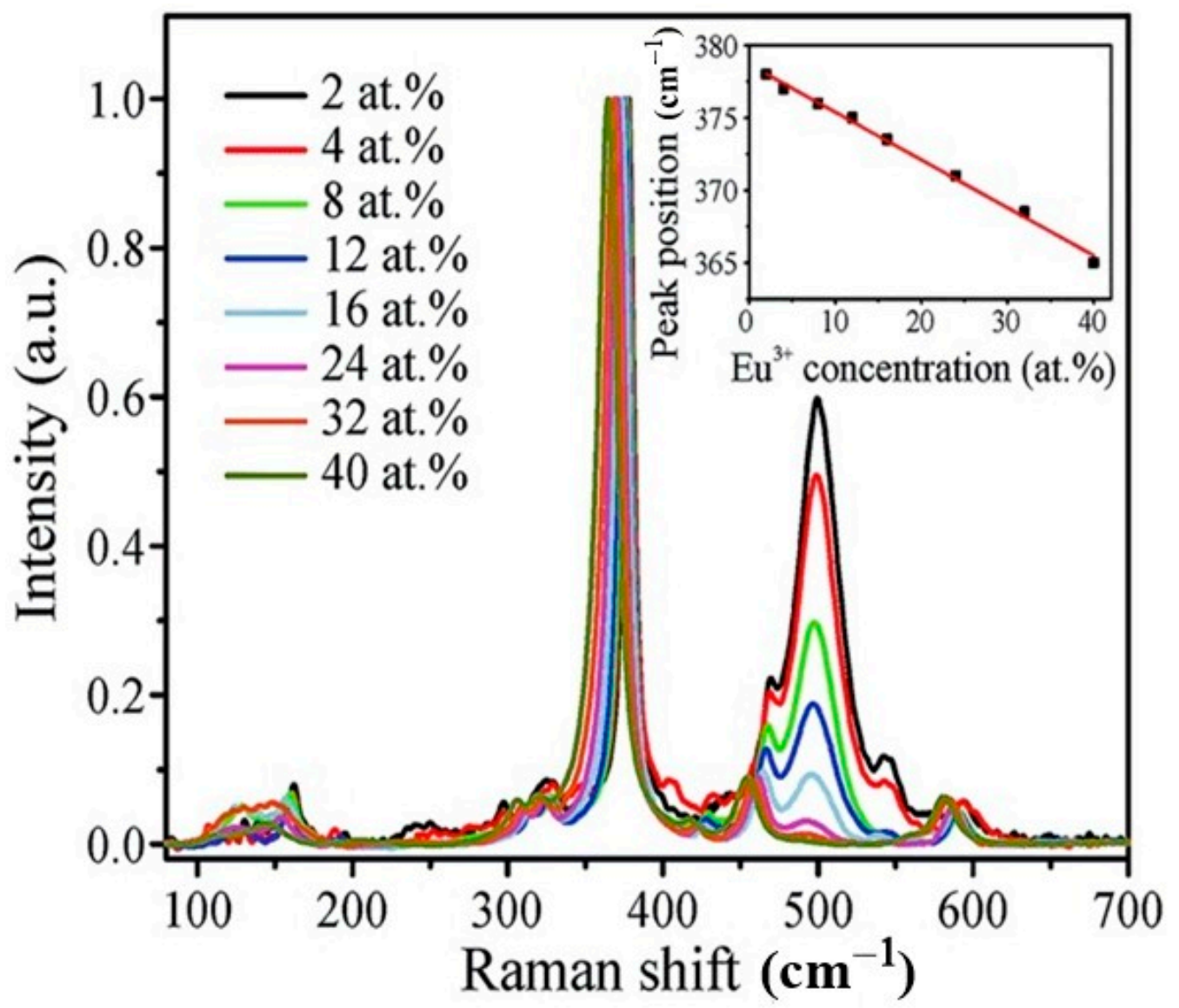

Figure 2. Raman spectra of $\mathrm{Y}_{2} \mathrm{O}_{3}: \mathrm{Eu}^{3+}$ concentration series (reprinted with permission from Reference [70]). 


\subsection{Flame Spray Pyrolysis (FSP)}

The two common methods of flame synthesis methods are flame spray pyrolysis (FSP), and flame assisted spray pyrolysis (FASP) [71] (Figure 3). In the FSP method, the fuel can even be the solvent of the precursor solution, and in FASP, gas is used as a fuel, and water is the solvent of the precursor solution [72]. In the FASP process, the correlation between particle size and crystalline phase of $\mathrm{Y}_{2} \mathrm{O}_{3}$ : Eu particles was established with the interaction of Eu-doping concentration. Monoclinic $\mathrm{Y}_{2} \mathrm{O}_{3}$ : Eu particles as a cubic crystal structure can be obtained through the post-processing method by flame synthesis [73]. This reaction is against the advantage of flame aerosol synthesis. When cubic $\mathrm{Y}_{2} \mathrm{O}_{3}$ : Eu particles were synthesized via high-temperature aerosol synthesis, the substrate was formed in the absence of quenching effect [74,75]. $\mathrm{Y}_{2} \mathrm{O}_{3}$ : Eu particles exhibit a similar size as $\mathrm{Y}_{2} \mathrm{O}_{3}$ particles when synthesized in flame synthesis [76]. The undesirable hollow morphology with irregular shapes can be obtained in the air-supported flame method. The particle morphology can also be improved by varying the precursor solution $[75,77]$, and dense, spherical $\mathrm{Y}_{2} \mathrm{O}_{3}$ : Eu particles can be generated using high flame temperatures, without the use of additives [73].

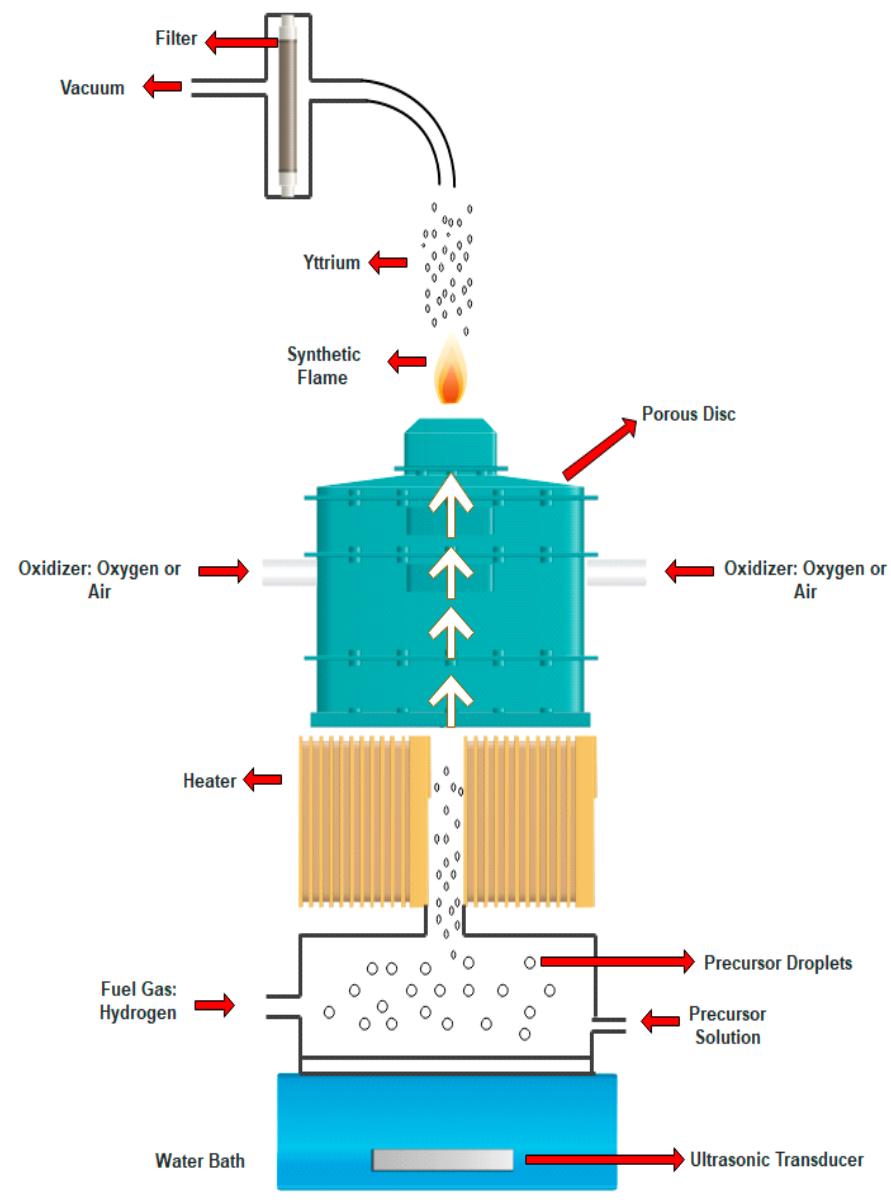

Figure 3. Schematic of the flame synthesis apparatus [71].

\subsection{Citrate Precipitation Method}

Among the many kinds of rare earth oxides, $\mathrm{Y}_{2} \mathrm{O}_{3}$ contains excellent temperature tolerability, corrosion resistance ability, and photochemical stability [78]. Several studies on the synthetic methods of nanoparticles have been carried out [79]. In this method, $\mathrm{Y}_{2} \mathrm{O}_{3}$ was prepared from $\mathrm{YCl}_{3}$ as precursors, $0.1 \mathrm{~mL} / \mathrm{L} \mathrm{YCl}_{3}$ and $0.1 \mathrm{~mol} / \mathrm{L} \mathrm{HCl}$ were mediated by PEG 2000 surfactant, and the dried process was performed using azeotropic distillation. Chen et al. [80] have found that homogenous spherical $\mathrm{Y}_{2} \mathrm{O}_{3}$ NPs could be obtained with a size of $20 \mathrm{~nm}$ by calcining the precursor at $800^{\circ} \mathrm{C}$ for $1 \mathrm{~h}$. This study was the first attempt 
at dry precipitation using azeotropic distillation under the least pressure, which confers quick NPs.

\subsection{Microplasma-Assisted Method}

In the nanoparticle synthesis process, plasma electrochemistry has emerged as a unique priority area of interest. Lin et al. [33] reported a peculiar method of $\mathrm{Y}_{2} \mathrm{O}_{3}$ preparation method using an easy handling, toxicity-free, microplasma-mediated synthetic process. It has worked in pin to liquid configuration with yttrium nitrate aqueous solution as precursors. Using this method, NPs with high purity and convenient size could be fabricated. This synthesis method contributes to an environmentally friendly and measurable route for $\mathrm{Y}_{2} \mathrm{O}_{3} \mathrm{NPs}$ generation.

\subsection{Acid Composition Mediated Method}

This method involved the dissociation of yttrium, ytterbium, and europium oxides using acetic, nitric, and $\mathrm{HCl}$ by dissociating acids, followed by hydrothermal technique supported by microwave irradiation and calcination process to confer NPs. Nunes et al. [32] recently reported the preparation of up-converted NPs consisting of Yttrium oxide, codoped with Ytterbium and Europium oxides using triple acids, and the size of the nanoparticles was $50 \mathrm{~nm}$. Thermal behavior was tested using differential scanning calorimetry (DSC) and X-Ray diffraction; it was noteworthy that acetic acid-based nanostructures offer nanosheets in nm size, whereas hydrochloric acid and nitric acid produce sphere-shaped NPs. These findings pave the way for NPs to be used in infrared-to-visible up-convertors, and applications to be explored in optoelectronic devices.

\subsection{Extraction of $\mathrm{Y}_{2} \mathrm{O}_{3}$ Synthesis}

A solvent extraction method was used to isolate and recover yttrium from the original leaching solution from the fluorescent lamp waste powder dissolved by sulfate and its optimizing the operational conditions, including reaction $\mathrm{pH}$, equilibrium time, the concentration of extractants, and $\mathrm{O} / \mathrm{A}$ (organic or aqueous phase) ratio, through the selection of four extractants that have different chemical features on rare earth metals (REM) extraction. The reaction mechanisms with yttrium by each extractant, yttrium was confirmed to form complex compounds at concentration ratios of 1:3, 1:1, and 1:2 with Versatic Acid 10, D2EHPA, and TOPO, respectively [81]. The recovery potential of yttrium from fluorescent lamp waste was determined by using a hydrometallurgical process. Leaching of metals from the waste was studied by applying acids viz. hydrochloric acid $(\mathrm{HCl})$, nitric acid $\left(\mathrm{HNO}_{3}\right)$ and sulfuric acid $\left(\mathrm{H}_{2} \mathrm{SO}_{4}\right)$. The influence of various factors (solid: liquid ratio, reaction temperature, reaction time, and acid concentration) was conducted by full factorial design for the recovery of yttrium. For the development of a viable hydrometallurgy approach to treating fluorescent lamp waste effectively, more research is still needed for the usage of information and expertise at different chemical handling stages, by considering various constraints in terms of economy and environment [82].

\subsection{Green Synthesis}

Despite the synthesis of $\mathrm{Y}_{2} \mathrm{O}_{3}$ NPs using several sources and methods, the Green method is suitable and is targeted by many researchers. Several studies have reported the plant-based nanoparticles using various parts of the plant (leaf, fruits, and pods), and as-prepared nanoparticles were tested and confirmed by characterization measures, such as UV-vis, XRD, Fourier-transform infrared spectroscopy (FTIR), Scanning Electron Microscopy (SEM), and Transmission electron microscopy (TEM). $\mathrm{Y}_{2} \mathrm{O}_{3}$ nanoparticles were green synthesized using Acalypha indica leaf extract, with a particle size ranging (23 to 66) $\mathrm{nm}$. The presence of $\mathrm{Y}-\mathrm{O}-\mathrm{Y}$ confirmed the formation of the synthesized nanoparticles, and $\mathrm{O}-\mathrm{Y}-\mathrm{O}$ stretching vibration using FTIR spectroscopy, changes in thermal behavior via thermogravimetric, and differential scanning calorimetry analyses [63]. Basavegowda et al. [83] also demonstrated green synthesized $\mathrm{Y}_{2} \mathrm{O}_{3}$ NPs using Liriope platy- 
phylla rhizome extract. It was reported that the leaf extract acts as the reducing agent when added to the solution of yttrium nitrate hexahydrate without any additives for the synthesis of nanoparticles, and the prepared nanoparticles were used as a heterogeneous green catalyst for the construction of biologically interesting 1,3-thiazolidin-4-ones in good-to-excellent yields

Kannan and Sundarajan [17] synthesized $\mathrm{Y}_{2} \mathrm{O}_{3}$ NPs using an aqueous extract of Acalypha indica as a capping agent. Ultraviolet-visible (UV-Vis) spectrogram was measured for all calcined NPs, and $\mathrm{Y}_{2} \mathrm{O}_{3}$ was found at $284.0 \mathrm{~nm}$. XRD for the yttrium complex showed an amorphous structure with a broad peak at the calcined $\mathrm{Y}_{2} \mathrm{O}_{3}$ NPs, and high-intensity peaks that belong to the cubic structure with $\mathrm{Ia}_{3}$ group. The lattice parameters (ao) are (10.37 $+0.01) \AA$ and at $90.00^{\circ}$. The FT-IR spectrum of $\mathrm{Y}_{2} \mathrm{O}_{3}$ showed a sharp band that appeared at $565 \mathrm{~cm}^{-1}$ that is assigned to $(\mathrm{Y}-\mathrm{O})$ stretching vibration and $\mathrm{Y}_{2} \mathrm{O}_{3}$ formation, while the intense band at $588 \mathrm{~cm}^{-1}$ indicates the presence of $\mathrm{Y}-\mathrm{O}-\mathrm{Y}$ asymmetric stretching mode of vibration corresponding to the surface-bridging oxide. The bands at $(873,1216,1085$, and 1026) $\mathrm{cm}^{-1}$ represent the $\mathrm{Y}-\mathrm{OH}$ and $\mathrm{Y}-\mathrm{O}-\mathrm{Y}$ groups present in the nanostructure. Another study has also emphasized that a green step approach was employed using Forsythiae fructus aqueous fruit extract. $\mathrm{Y}_{2} \mathrm{O}_{3}$ NPs were successfully developed recently [37], and the obtained nanoparticles were reported to exhibit anticancer activity against harmful pathogens. The nanoparticles' size was $11 \mathrm{~nm}$. The green synthetic method showed environmentally friendly, cheap, and reduced toxicity of chemical and less harmful side effects. This method can be widely advocated as an alternative to expensive physical and chemical $\mathrm{Y}_{2} \mathrm{O}_{3}$ NPs preparation and used as a promising candidate for clinical applications.

\section{Biomedical Applications of Yttrium Oxides Nanoparticles}

NPs have been synthesized and analyzed for various biomedical applications, such as biomedical materials, as a prediction marker for identifying deadly diseases in advance, such as cancer-related diseases [84-88]. $\mathrm{Y}_{2} \mathrm{O}_{3}$ has proved to be a potent element and is used in the biomedicine field. In this section, we discuss applications of $\mathrm{Y}_{2} \mathrm{O}_{3}$ in antibacterial activity, anticancer and hepatoprotective actions, and present neuroprotective activities (Figure 4).

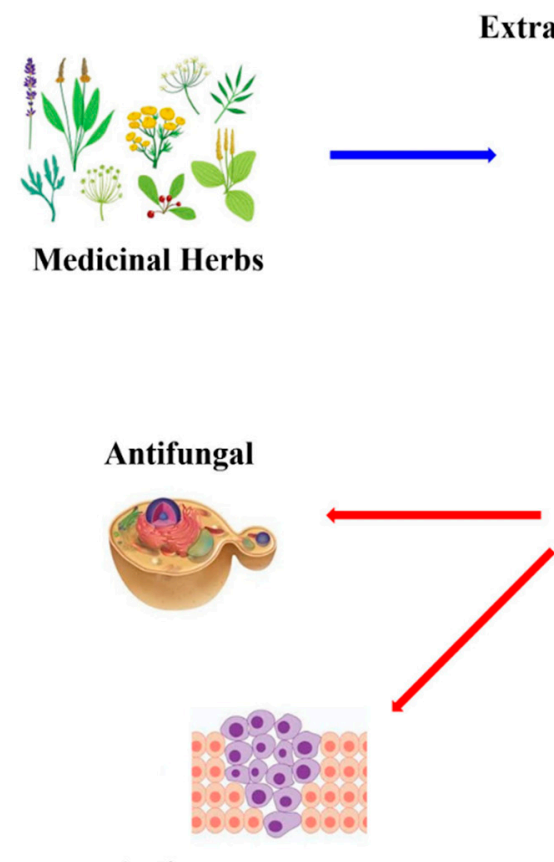

Anticancer
Extraction

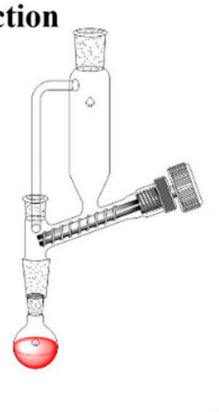

$\because$

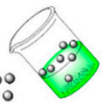

Yttrium Salts

$\mathrm{Y}_{2} \mathrm{O}_{3} \mathrm{NPs}$
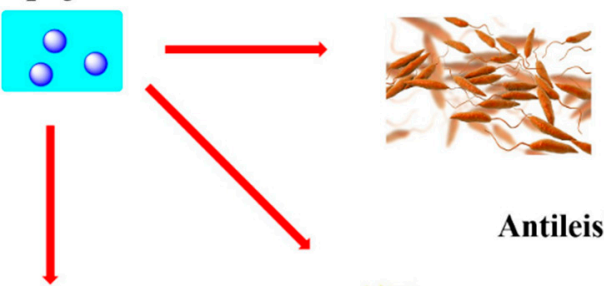

Antileishmania

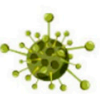

Antivirus

Antibacterial

Figure 4. Biomedical applications of yttrium oxides nanoparticles $\left(\mathrm{Y}_{2} \mathrm{O}_{3} \mathrm{NPs}\right)$. Blue arrow indicates that synthesis of $\mathrm{Y}_{2} \mathrm{O}_{3}$ NPs and red arrow indicates that biomedical applications of $\mathrm{Y}_{2} \mathrm{O}_{3}$ NPs. 


\subsection{Antibacterial Activity}

$\mathrm{Y}_{2} \mathrm{O}_{3}$ has been shown to reportedly contain the ability of bacterial growth suppressor against both gram-positive and gram-negative harmful pathogens. The actions of $\mathrm{Y}_{2} \mathrm{O}_{3}$ can be divided into two types. Firstly, $\mathrm{Y}_{2} \mathrm{O}_{3}$ gets directly into the bacterial cell wall and activates intracellular reactive oxygen species (ROS). Kannan and Sundarrajan et al. [17] have reported that plant leaf extract of Acalypha indica used NPs were found to be effective against E. coli, P. aeruginosa, S. marcens, and S. aureus, and minimum concentration was recorded as $\left(11,10,13\right.$, and 13) $\mu \mathrm{g} \mathrm{m}^{-1}$, respectively. The optimum concentration of $\mathrm{Y}_{2} \mathrm{O}_{3}$ NPs required was reported to be $(8-10) \mu^{-1}$. The mechanism involved is still not precise. It was understood that $\mathrm{Y}_{2} \mathrm{O}_{3}$ nanoparticles, after invading the bacteria, act on their enzymes to inactivate them. They subsequently enhance hydrogen peroxide production that leads to bacterial cell death. It has been noted that the outcomes of their experiments indicated $\mathrm{Y}_{2} \mathrm{O}_{3}$ NPs enable the cellular metabolism of the organism to be suppressed, causing the fatality of bacteria, and $\mathrm{Y}_{2} \mathrm{O}_{3}$ could be used as an effective growth inhibitor of several pathogens and offers scope as an antimicrobial regulating system. Another study demonstrated by Lelloucle et al. [40] has described a water-based synthesis of yttrium fluoride NPs using the sonochemical irradiation process. In their studies, E. coli and Staphylococcus aureus were used as bacterial pathogens with $\mu \mathrm{g} / \mathrm{ML}$ range. They suggested that antimicrobial activity was dependent on the size of the NP and highlighted that yttrium-based NPs have been used to develop antimicrobial and active biofilm production, which was attributable to their low solubility conferring external protection on the cell organelles.

The application of NPs as antimicrobials could contribute to an innovative model of targeting cellular organelles with existing antibiotics $[84,89,90]$. Recently, Slate et al. evaluated the metal ion of yttrium, molybdenum, and thallium efficacy against bacteria K. pneumonia and Acinetobacter baumannii [91]. They found that higher concentration was needed to inhibit the growth of biofilms, compared to planktonic control. Minimal inhibitory concentration (MIC) of metal ions in planktonic cells does not affect biofilm. Yttrium ions and rhenium ions were possible for biofilm production. Wang et al. [92] used yttrium, $\mathrm{Zn}$, and $\mathrm{TiO}_{2}$ synergistically as antibacterial materials, and formed doping $\mathrm{Zn}$ and yttrium nanoparticles. They were reported to contribute great effectiveness to the antibacterial activity of $\mathrm{TiO}_{2}$. Several research reports provided that yttrium fluoride nanoparticles were added to the conventional orthodontic composite resin (Transbond XT) at different concentrations of prepared and showed significant antibacterial activity against Streptococcus mutans with adhesion strength comparable to a conventional resin that is responsible for enamel demineralization, causing white spot lesions $[93,94]$.

\subsection{Anticancer Activity}

In addition, antimicrobial, antibacterial, and antioxidant $\mathrm{Y}_{2} \mathrm{O}_{3}$ NPs exhibited a predominant anticancer ability. The preparation of NPs using natural products has attracted remarkable and increased interest, due to its unmatched resources, inexpensive nature, and as an alternative to chemicals with non-toxicity and offering no biological risk [95] or side effects. Recently, Basavegowda et al. [83] have demonstrated the synthesis of NPs using Liriope platyphylla rhizome extract with a size of $17 \mathrm{~nm}$ that reportedly exhibited anticancer activity. Similarly, Nagajyothi et al. [39] have reported $\mathrm{Y}_{2} \mathrm{O}_{3}$ synthesis involving Forsythiae fructus aqueous fruit extract and validated its anticancer ability against kidney cancer cell lines, such as Madin-Darby Canine Kidney (MDCK) and Caki-2. The results showed a flake-like flower appearance of NPs with a size of $11 \mathrm{~nm}$. The toxicity effect reveals that NPs exhibited no toxic effect on the normal MDCK cells, while more toxicity to renal cancer cells in high concentration was reported in Figure 5. 


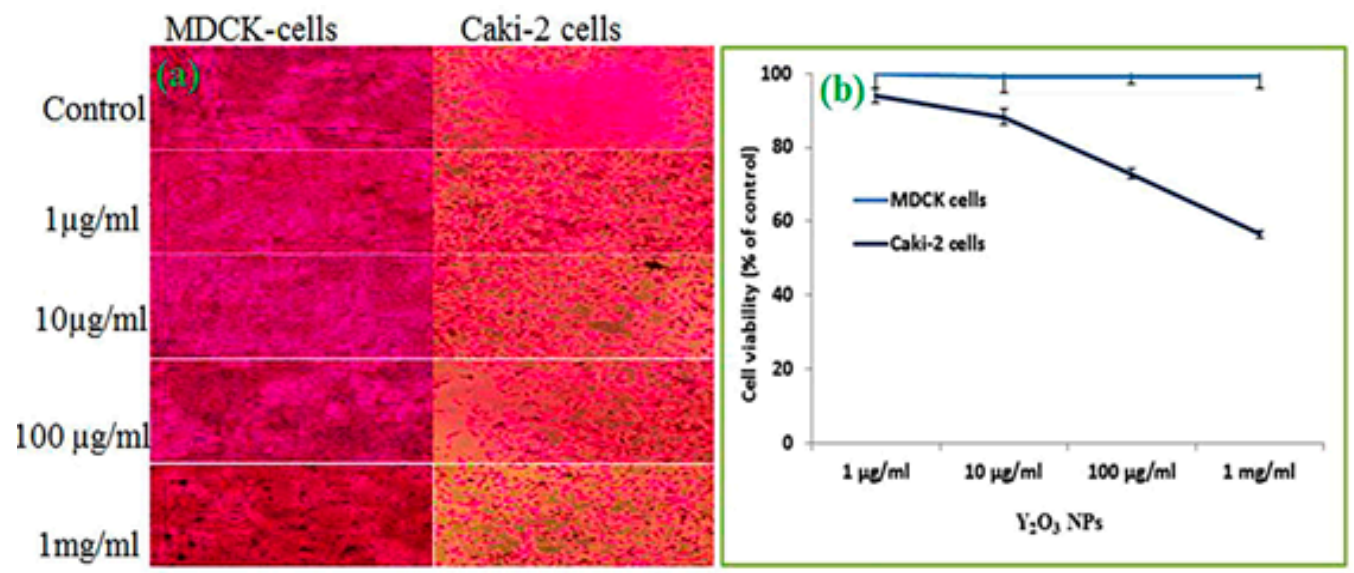

(c)
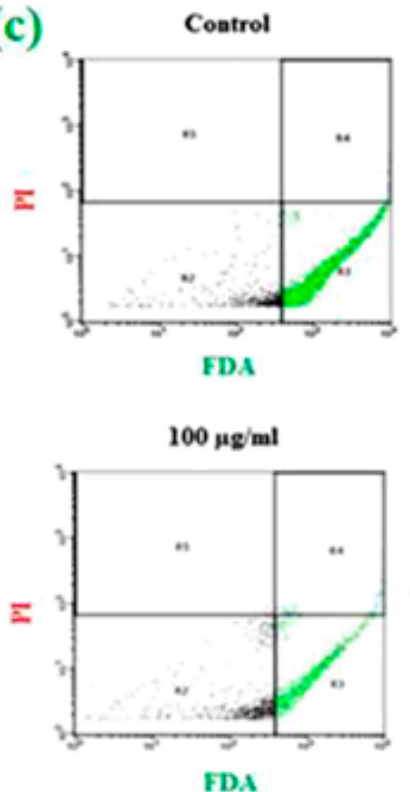
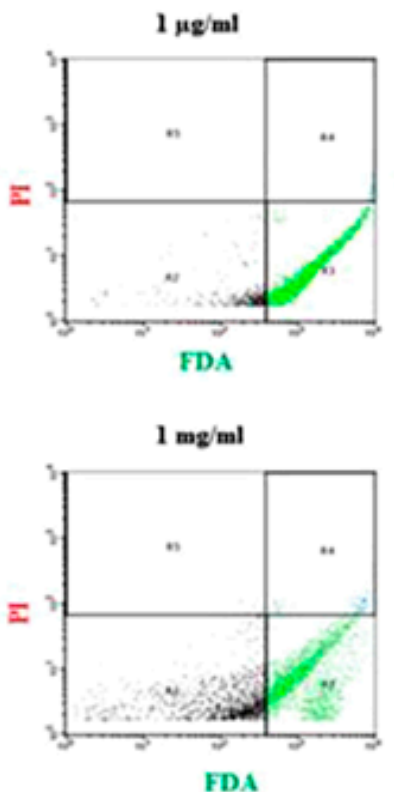
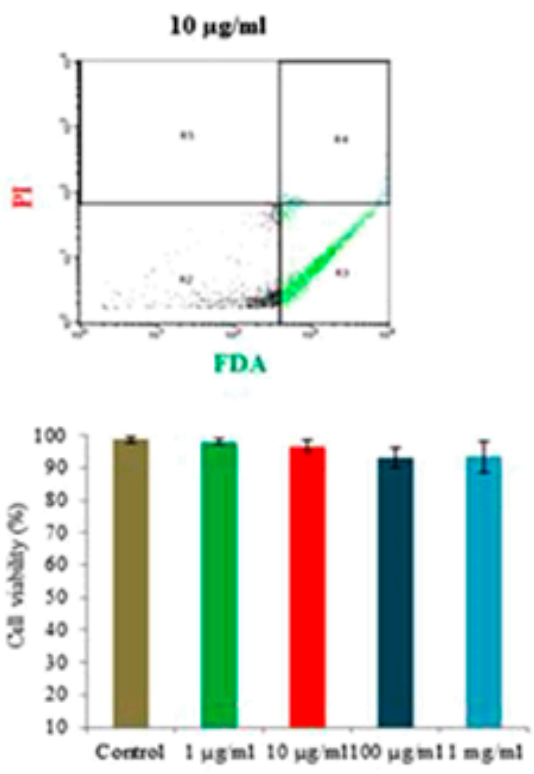

Figure 5. (a) Microscopic images of Madin-Darby Canine Kidney (MDCK) and Caki-2 cells. (b) Cytotoxic effect of $\mathrm{Y}_{2} \mathrm{O}_{3} \mathrm{NPs}$ on MDCK and Caki-2 cells by SRB assay at $24 \mathrm{~h}$. Values were expressed as means \pm mean standard error (MSE). (c) Effect of $\mathrm{Y}_{2} \mathrm{O}_{3}$ NPs on the Caki-2 cells discriminated by Fluorescein diacetate (FDA) and propidium iodide (PI). Area R3 is FDA positive, R5 is PI-positive, R4 is both FDA and PI-positive, and R2 is both FDA and PI negative. Effect of $\mathrm{Y}_{2} \mathrm{O}_{3}$ NPs on Caki-2 cell viability was examined at $24 \mathrm{~h}$ (Reprinted with permission from [39]).

Hosseini et al. [96] have suggested the combined effects of $\mathrm{Y}_{2} \mathrm{O}_{3}$ and cerium oxide protected beta-cell apoptosis by accelerating the oxidative stress-dependent apoptotic pathway. In tissue engineering, $\mathrm{Y}_{2} \mathrm{O}_{3}$ finds other applications in which metal oxide $\left(\mathrm{Y}_{2} \mathrm{O}_{3}\right)$ NPs are embedded in polycaprolactone (PCL) scaffolds to enhance the proliferation of endogenous cells, and exhibited angiogenic properties. The findings of the experiment reported that the presence of $\mathrm{Y}_{2} \mathrm{O}_{3}$ in the scaffolds upregulates the cell expression of proliferation-associated molecules, like vascular endothelial growth factor (VEGF) and epidermal growth factor receptor (EGFR). The study concluded that $\mathrm{Y}_{2} \mathrm{O}_{3}$ NPs play a crucial part in tissue engineering scaffolds to induce proliferation and angiogenesis. NPs offer cytoprotection to healthy cells from ROS impacts. However, they attract and kill cancer cells using enhanced ROS generation. Cancer cells possess an acidic microenvironment, due to its series of biochemical reactions, such as glycolysis, and produced lactic acid accumulation [97] prevailed. Polyethylene glycol methacrylate phosphate (Poly-EGMP) yttrium NPs proved to be safe up to $0.1 \mathrm{mg} / \mathrm{g}$ body weight in 1-month-old Sprague-Dawley rats, showing also the ability to cross the blood-brain barrier a short time after tail injection. 
The surface modification of yttrium NPs here described allows these NPs to be potentially used in theranostics to reduce neurodegenerative damage due to heat stress [98]. Noncationic nanomaterials that adsorb DNA but cannot quench fluorescence are less known. These materials are attractive for studying the mechanism of DNA-based surface reactions. $\mathrm{Y}_{2} \mathrm{O}_{3}$ was found to have this property and it has been used for fluorescently labeled oligonucleotides as probes to study the mechanism of DNA adsorption [99]. Therefore, $\mathrm{Y}_{2} \mathrm{O}_{3}$ is a potential option for inhibiting the growth of cancer cells.

\subsection{Hepatoprotective Role of $\mathrm{Y}_{2} \mathrm{O}_{3}$}

Nanotechnology is represented by nanoscale materials with appealing physicochemical and biological features and has received increasing attention. These materials are used as different therapeutic agents for treating diseases, including hepatic cellular-related disorders. Recently, Song et al. [100] have reported that $\mathrm{Y}_{2} \mathrm{O}_{3}$ NPs injection of $30 \mathrm{mg} / \mathrm{kg}$ increased hepatic antioxidant status, and suppressed the antioxidant stress and inflammatory responses in lipopolysaccharide-induced mice. They also found that $\mathrm{Y}_{2} \mathrm{O}_{3} \mathrm{NPs}$ have inhibited hepatic NF-kB induction, apoptosis, and liver injury, and explored them as an innovative therapeutic strategy for treating fulminant hepatic failure. Moreover, it has been observed effectively in oxidative stress-associated diseases. Similarly, another study reported by Hosseni et al. [96] reported that yttrium oxide nanoparticles with cerium oxide have effectively exhibited antioxidant behavior by activating ROS, and a key need for cell apoptosis was well established.

\subsection{Actions as Antioxidant}

Currently, nanotechnology and nanoparticle usage is a growing research area. ROS represents hydroxyl radical $(\mathrm{OH})$, superoxide radical $\left(\mathrm{O}_{2}\right)$, and hydrogen peroxide $\left(\mathrm{H}_{2} \mathrm{O}_{2}\right)$. Among them, $(\mathrm{OH})$ group attracts and associates with lipids, proteins, and nucleic acids that lead to the disintegration of the outer membrane of organelles, and causes functional deterioration in genetic materials and proteins [101]. To compensate for the toxic effect of ROS, the body activates antioxidant defense responses, viz. enzymatic and nonenzymatic components [102]. Oxidative stress is known to cause several complex diseases, including diabetes mellitus [103]. Increased oxidative stress, coupled with an increased level of ROS caused the injury, and splitting cellular DNA strand was reported [104]. $\mathrm{Y}_{2} \mathrm{O}_{3}$ is a metal oxide that exhibits remarkable free energy of oxide formation sourced from elemental oxide. $\mathrm{Y}_{2} \mathrm{O}_{3}$ NPs enable protection of the cells from oxidative stress-induced cell death, based on the structure of the particles, and the unique nature of its size in the range (6-1000) $\mathrm{nm}$ [105]. In recent times, the use of silver nanoparticles in diabetic wound healing therapy was also reported. Other oxide NPs are synthesized, and proved to be a free radical scavenger [106].

Several researchers on various cell types have investigated the antioxidant properties of $\mathrm{Y}_{2} \mathrm{O}_{3}$. A higher concentration of $\mathrm{Y}_{2} \mathrm{O}_{3}$ NPs enhanced the production of reactive oxygen species (ROS) in cells, leading to stimulating the immune system. A study conducted by Hosseini et al. [96] reported the effects of cerium oxide NPs and $\mathrm{Y}_{2} \mathrm{O}_{3}$ on pancreatic islets, and the effects of $\mathrm{Y}_{2} \mathrm{O}_{3}$ and $\mathrm{CeO}_{2} \mathrm{NPs}$ on anti-apoptosis in a rat model. The combination of $\mathrm{Y}_{2} \mathrm{O}_{3}$ and $\mathrm{CeO}_{2} \mathrm{NPs}$ inhibited the oxidant production and apoptosis and high viability of normal cells, and insulin secretion was also observed. These indicated $\mathrm{Y}_{2} \mathrm{O}_{3}$ and $\mathrm{CeO}_{2} \mathrm{NPs}$ may be involved in the protection of beta-cell apoptosis by accelerating oxidative stress. Currently, another study carried out by Aglan et al. [107] has explored that $\mathrm{Y}_{2} \mathrm{O}_{3}$ NPs and $\mathrm{CeO}_{2} \mathrm{NPs}$ exerted efficient antioxidant potential, and could be used in the proliferation of mesenchymal stem cells (MSCs). Various sizes of $\mathrm{Y}_{2} \mathrm{O}_{3}$ influenced the morphology, and the proliferative potential of MSCs are proved to be $\mathrm{Y}_{2} \mathrm{O}_{3}, \mathrm{CeO}_{2} \mathrm{NPs}$ participating in intensifying the proliferation process of the human dental pulp. Earlier reports have speculated that the well-known free radical scavenger effects of $\mathrm{Y}_{2} \mathrm{O}_{3}$ NPs are attributed to their non-stoichiometric crystal structure [108]. In 2006, Schubert et al. [109] also studied the $\mathrm{Y}_{2} \mathrm{O}_{3} \mathrm{NPs}$ effects on nerve cells, and their protection from the lethality of the cells from oxidative stress and neuroprotection is reportedly independent of particle size. Yttrium 
oxide can serve as an antioxidant to control or neutralize the ROS needed to exterminate the cells. Therefore, $\mathrm{Y}_{2} \mathrm{O}_{3}$ has played a crucial role in antioxidant and neuroprotective against oxidative stress and apoptosis in vivo.

\section{Drug Delivery Applications}

$\mathrm{Y}_{2} \mathrm{O}_{3}$ physiochemical properties have also been used in several biomedicine applications and utilized as potential drug delivery vehicles. This application targeted at cancer cells has shown to be a combined anticancer effect, due to its cytotoxic ability towards cancer cells. Many researchers studied $\mathrm{Y}_{2} \mathrm{O}_{3}$ NPs using drug delivery methods. Jia et al. [110] have synthesized similar-sized NPs derived from melamine-formaldehyde (MF) templates, followed by calcination, and counted crystalline $\mathrm{Y}_{2} \mathrm{O}_{3}$ precursors to $\mathrm{Y}_{2} \mathrm{O}_{3}$ NPs during the annealing process. The shell of hollow nanospheres was filled with numerous NPs of a similar size. Moreover, a lanthanide activator $\mathrm{Ln}^{3+}$ doped with $\mathrm{Y}_{2} \mathrm{O}_{3}$ NPs was synthesized, and such NPs were found to be bright and sensitive to up-and-down-conversion of luminescence ability with a diverse color source. The nanoparticles have proved to be an effective drug vehicle for cancer-related diseases. Another study conducted by Patra et al. [111] has recently reported that yttrium oxide fluorescence and magnetic, bifunctional nanoparticles have shown an unmatched application, including nano drugs. Their findings demonstrated bifunctional hollow microsphere (BHMs) hollow core structures that were designed and loaded with ibufrotus drugs. This was examined in preclinical research, and showed that BHMs executed appreciable drug delivery and loaded capacity (126 mg/g). Moreover, a prolonged time of drug release was also observed. This ability provides insight into employing these $\mathrm{Y}_{2} \mathrm{O}_{3}$ NPs as drug carriers targeting cancer cell therapy.

Microscopic particles are great to deal with the increasing interest in the cytotoxicity of NPs [112]; few researchers have studied the responses of nerve cells exposed to NPs. However, there are limited studies to examine the biological consequences of synthetic nanoparticles. Soto et al. [113] determined the cytotoxicity of a group of NPs on the wellrecognized cell line of murine macrophages and showed that a diverse group of NPs is cytotoxic. David Schubert et al. have reported that $\mathrm{Y}_{2} \mathrm{O}_{3} \mathrm{NPs}$ have shown the rescue role of nerve cells from oxidative stress in HT22 cells [109]. Neuroprotection is associated with the size of the NPs. The study revealed that $\mathrm{Y}_{2} \mathrm{O}_{3}$ NPs served as a direct antioxidant, and blockaded the ROS production. The mode of action was stimulated by reducing the level of ROS production that speeds up and activates ROS defense mechanism, prior to glutamate-induced apoptosis being complete. This occurred while exposure of cells to the NPs reportedly stimulated a low level of ROS [114]. ROS in the best way to predict direct antioxidants in intact cells [115]. $\mathrm{Y}_{2} \mathrm{O}_{3}$ NPs are able to curtail the pools of generated ROS non-NPs oxides or salts that are not protective that indicated size and structure determinations for the antioxidant efficiency of NPs. However, it has been reported that the neuroprotective response purely depends upon the physiochemical and characteristics of exposed nanoparticles and their size. They demonstrated $\mathrm{Y}_{2} \mathrm{O}_{3}$ NPs showed more potent antioxidants than $\mathrm{CeO}_{2}$. Thus, it can be concluded that $\mathrm{NPs}$ of $\mathrm{Y}_{2} \mathrm{O}_{3}$ can help the survival of nerve cells under oxidative stress, which could be used for therapeutic applications.

\section{Luminescence and Imaging}

$\mathrm{Y}_{2} \mathrm{O}_{3}$ is a white solid thermal material that is stable and is used for conferring orange to red in the television picture tube. It offers purity of color and stability. $\mathrm{Y}_{2} \mathrm{O}_{3}$ is used for emission display vacuum fluorescent display, and its physical properties were exploited in the plasma display panel and the electroluminescence, cathodoluminescence, and thermoluminescence fields [28]. $\mathrm{Y}_{2} \mathrm{O}_{3}$ use in solar energy conversion devices, UV radiation emitters, and telecommunication devices has been reported, due to its high bandgap $[116,117]$. This showed an effective permittivity and clean transparency to IFR radiation [118-121], with a melting point of $2439{ }^{\circ} \mathrm{C}$ [119]. Due to the ionic radius of $\mathrm{Y}^{3+}$ being similar to rare-earth doping $\mathrm{Y}_{2} \mathrm{O}_{3}$ nanoparticles, they have been used as rare-earth-doped yttrium materials [122]. Several studies demonstrated that $\mathrm{Y}_{2} \mathrm{O}_{3}$ has diverse applications 
in material sciences. $\mathrm{Y}_{2} \mathrm{O}_{3}$ potential in thermal stability, superior infrared transmission range ((1-8) micron wavelength), and erosion resistance ability enables them to be used as a unique material in protection domes for the infrared sensor, temperature sensor, and solar cell sensors. Moreover, they have been used in ultrafast sensors in X-rays.

The research reports indicated that the nanoparticles can be synthesized with different sizes, shapes, and optical properties by various methods. The appealing property of emission of red light was used for the manufacture of fluorescent lamps. The current study showed that $\mathrm{Y}_{2} \mathrm{O}_{3}$ doped with rare-earth ions had been used for solid-state lighting purposes [123]. The $\mathrm{Y}_{2} \mathrm{O}_{3}$ doped $\mathrm{Eu}^{3}+$ ions $\left(\mathrm{Y}_{2} \mathrm{O}_{3}: \mathrm{Eu}^{3+}\right)$ act as a main oxide-based redemitting phosphor, which is used widely in the lighting industry and solid-state laser-based devices [124]. Luminescence investigation confirmed that the majority of the $\mathrm{Eu}^{3+}$ ions occupy the $\mathrm{Y}_{2} \mathrm{O}_{3}$ site, and luminescence intensity increases with particle size/crystallinity. While using PL, its images (Figure 6) are visible to the naked eye, and from this, the photoluminescence $(612 \mathrm{~nm})$ that is related to $\mathrm{Eu}^{3+}$ is high for $5 \mathrm{~mol} . \% \mathrm{Eu}^{3+}$ doping and more intense in the $900{ }^{\circ} \mathrm{C}$ annealed $\mathrm{Y}_{2} \mathrm{O}_{3}: \mathrm{Eu}^{3+}$ [125]. At the same time, there is a uniform emission of $\mathrm{Eu}^{3+}$ throughout the sample annealed at $600{ }^{\circ} \mathrm{C}$, while the comparatively less intense $\mathrm{Eu}^{3+}$ emission could be due to $\mathrm{OH}$ bonds associated with the matrix at such relatively low annealing temperatures [126]. The PL lifetime decreases with the dopant concentration from $((2.26$ to 1.77$)$ and from $(2.35$ to 1.81$)) \mathrm{ms}$ in the case of (600 and 900) ${ }^{\circ} \mathrm{C}$ annealing, respectively. The luminescence observed was strong in $\mathrm{Y}_{2} \mathrm{O}_{3}: \mathrm{Eu}^{3+}$ with slow decay (maximum decay time of $2.35 \mathrm{~ms}$ ), and it is a good candidate for interesting applications, such as biosensors and red components for white light LEDs. It could be a promising approach for fabricating optoelectronic thin films with high optical quality [125]. $\mathrm{Y}_{2} \mathrm{O}_{3}$ : $\mathrm{Eu}^{3+}$ phosphor powders were prepared by the Sol-combustion synthesis method using sulfur-containing organic fuel in ethanol-aqueous solution, and investigated how the structure, morphology, and luminescence intensities of these phosphors are affected by varying fuel-to-host ratios (S/Y) [127].

Upon excitation, $\mathrm{Eu}^{3+}$ doped systems indicate many Stark energy levels in the visible region. Luminescence transitions corresponding to the 5D0-7FJ manifold in the orange-red region are of practical significance [128]. The emission spectrum of the $\mathrm{Eu}^{3+}$ ion-doped in a $\mathrm{Y}_{2} \mathrm{O}_{3}$ matrix with different $\mathrm{S} / \mathrm{Y}$ molar ratios was obtained. The emission observed in the (514-700) nm range is ascribed to the well-known $\mathrm{Eu}^{3+} 5 \mathrm{D} 0 \rightarrow 7 \mathrm{FJ}\left(\mathrm{J} \frac{1}{4} 0,1,2,3\right.$ and 4) transitions. This prompts the formation of rare earth oxide by igniting first during heating, which leads to a combustion decomposition reaction. $\mathrm{Y}_{2} \mathrm{O}_{3}: \mathrm{Eu}^{3+}$ microcrystalline structures were obtained using thiourea as organic fuel [127].

Lin et al. [65] synthesized $\mathrm{Y}_{2} \mathrm{O}_{3}$ powder phosphors without metal activators by the sol-gel method, and they show an intense bluish-white emission (ranging 350 to $600 \mathrm{~nm}$, centered at $416 \mathrm{~nm}$ ) under a wide range of UV light excitation of 235-400 $\mathrm{nm}$. Since $\mathrm{Y}^{3+}$ itself is non-luminous, the observed luminescence from the $\mathrm{Y}_{2} \mathrm{O}_{3}$ samples must be related to chemical-bond breakage with resultant carbon formation, and/or the non-stoichiometry created by the oxygen deficiency in the system [129-131]. Here, the luminescent mechanisms have been ascribed to the carbon impurities in the $\mathrm{Y}_{2} \mathrm{O}_{3}$ host. This phosphor can be potentially used as a new efficient blue-emitting material for white LEDs [65]. $\mathrm{Y}_{2} \mathrm{O}_{3}$ is used in the multicolor imaging technique to understand the biological activity of cells using cathode luminescence (CL). In CL imaging, $\mathrm{Y}_{2} \mathrm{O}_{3}: \mathrm{Tm} ; \mathrm{Y}_{2} \mathrm{O}_{3}: \mathrm{Tb}$, and $\mathrm{Y}_{2} \mathrm{O}_{3}:$ Eu were involved as phosphors [132]. $\mathrm{Y}_{2} \mathrm{O}_{3}$ doped with europium was reported for the emission of red-orange color using agitation by cathode luminescence [133]. Recent literature emphasized that using the $\mathrm{CL}$ characteristics of $\mathrm{Y}_{2} \mathrm{O}_{3}$ with dope $\mathrm{Eu}$, a thin film can be generated by applying the magnetron sputtering method [134]. 

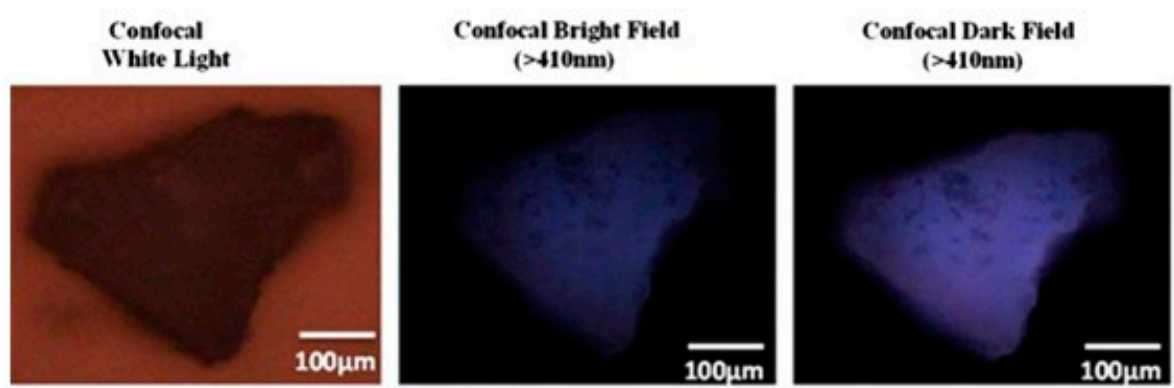

$\mathrm{Y}_{2} \mathrm{O}_{3}: \mathrm{Eu}^{\mathrm{s} *}(1 \mathrm{~mol} \%)$ at $900^{\circ} \mathrm{C}$
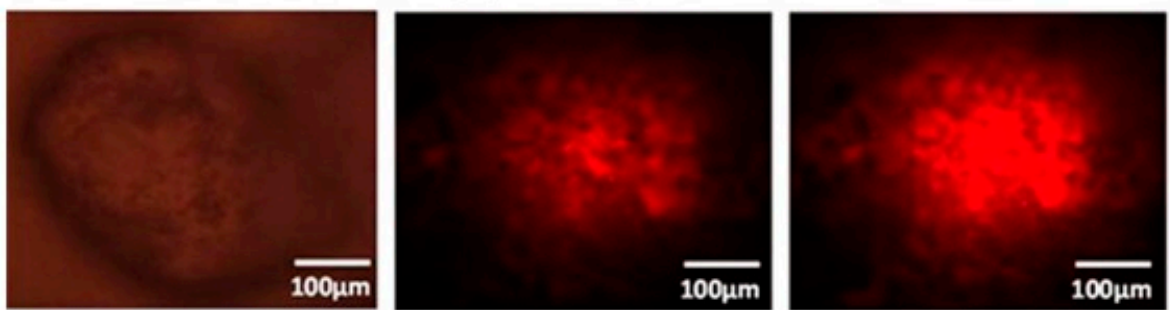

$\mathrm{Y}_{2} \mathrm{O}_{3}: \mathrm{Eu}^{3 *}(3 \mathrm{~mol} \%)$ at $900{ }^{\circ} \mathrm{C}$
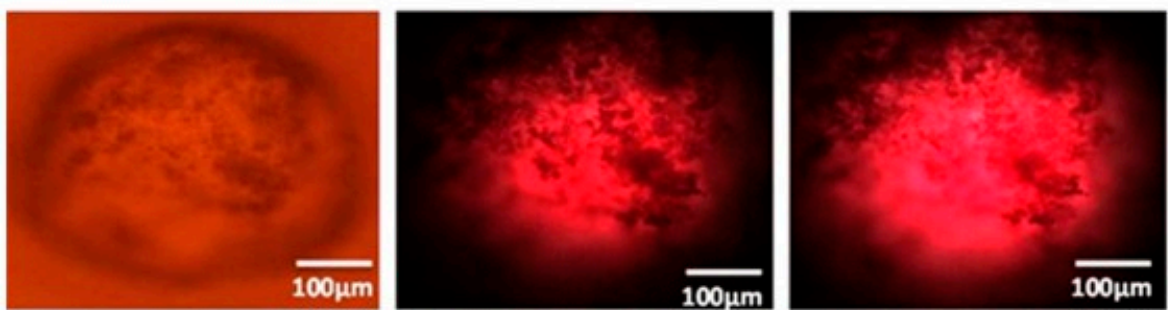

Y.O.: Eu" (5 mol\%) at $900{ }^{\circ} \mathrm{C}$

Figure 6. Confocal photoluminescence image of $\left(1,3\right.$, and 5) mol.\% Eu $3 \mathrm{u}^{3 \mathrm{~b}}$-doped $\mathrm{Y}_{2} \mathrm{O}_{3}$ nanoparticles annealed at $900{ }^{\circ} \mathrm{C}(\lambda \mathrm{ex}=410 \mathrm{~nm})$. (Reprinted with permission from Reference [125] Copyright $\odot$ 2017 Elsevier.).

This is an advanced key technology for biomedical research to image biological materials and is used for photodynamic therapy, the high sensitivity and superior resolution being attributed to its drug delivery system $[135,136]$. The mechanism involved is traditionally boilable for imaging, covering organic dyes (fluorescent protein and quantum dots). Such a boilable process has been used for fluorescence bioimaging (FBI) ultraviolet excitation or UV light. The fluorescent protein used themselves and biological organelles are damaged in responding to phototoxicity, due to the heavy quantum energy of the exciting light. A recent study demonstrated the surface modifications of $\mathrm{Y}_{2} \mathrm{O}_{3}$-Er with a couple of layers of PAAc used as interfacing materials, and acetal PeG-b-DAMA contributes to the successful NIR imaging of NPs [137]. NPs size of (10-200) nm was found to be suitable for infrared excitation. Another study explained Plasmon-enhanced up-conversion was reported in $\mathrm{Au} /$ Sio $\mathrm{Y}_{2} \mathrm{O}_{3}$, in which $\mathrm{Yb}^{3+}$ and $\mathrm{Er}_{2}$ showed a strong NIR emission under NIR excitation. Ukare et al. also noticed NIR emission across the swine colon wall [122]. Moreover, yttrium oxide was used as functional GAN-based MOS devices.

High-power lasers are applied in materials processing, remote sensing, communications, and inertial confinement fusion (ICF) [138]. $\mathrm{Y}_{2} \mathrm{O}_{3}$ doped NPs exhibit ceramic laser materials, and act as an added advantage. Another investigation demonstrated Tm-doped $\mathrm{Y}_{2} \mathrm{O}_{3}$ could be used as an eye safety laser [139]. Moreover, $\mathrm{Y}_{2} \mathrm{O}_{3}$ acts as active microwave filters $[140,141]$. Therefore, $\mathrm{Y}_{2} \mathrm{O}_{3}$ can be a candidate in luminescent display devices for a non-toxic, good host for light-emitting materials in laser and sensor devices, and used as a phosphor in LED. Current literature favored that $\mathrm{Y}_{2} \mathrm{O}_{3}$ can be used in advanced technology photodynamic therapy and the drug delivery system. In addition to producing permanent magnets and microwave filters, it can finally be concluded that $\mathrm{Y}_{2} \mathrm{O}_{3} \mathrm{NPs}$ morphology and 
size of particles enhanced its apparent elegant nature, and can be used in high-resolution display optical devices.

NPs technology is quite a speedily developing field and is showing a bright scope for biomedical applications. Recently, advanced techniques, such as photonics, and biophotonics research, have turned to a particular emphasis on the development of surface extended and functionalized NPs for therapeutic diagnosis and targeted treatments for several diseases. Bioimaging and predicting disease markers required fabricated NPs with a nanosize of $25 \mathrm{~nm} . \mathrm{Y}_{2} \mathrm{O}_{3}$ NPs were found to possess two photons that enabled them to convert infrared light to visible light. Another related study has demonstrated that an organic, inorganic hybrid class with yttrium oxides NPs were synthesized using a sol-gel process with proper zirconium side, yttrium chloride, water, and chloroform to obtain $\mathrm{H}$ bonds between $\mathrm{Zn}-\mathrm{OH}$ group. A single step of the sol-gel process was followed to precipitate NPs, possessing ketoprofen used for controlled drug delivery [36]). Such synthesized NPs derived by the sol-gel method enable a novel approach for a controlled drug delivery system. Microscopic NIR fluorescence images of histological sections of mice kidney confirmed that within $1 \mathrm{~h}$, some 50 and $250 \mathrm{~nm}$ nanoparticles had entered the glomerulus part of the kidney, suggesting that some of the injected nanoparticles may be excreted. NIR fluorescence emission from histological sections of the liver samples confirmed the difference in the distribution patterns of PEG-b-PAAc-modified and unmodified $\mathrm{Er}^{3+}: \mathrm{Y}_{2} \mathrm{O}_{3}$ (Figure 7).
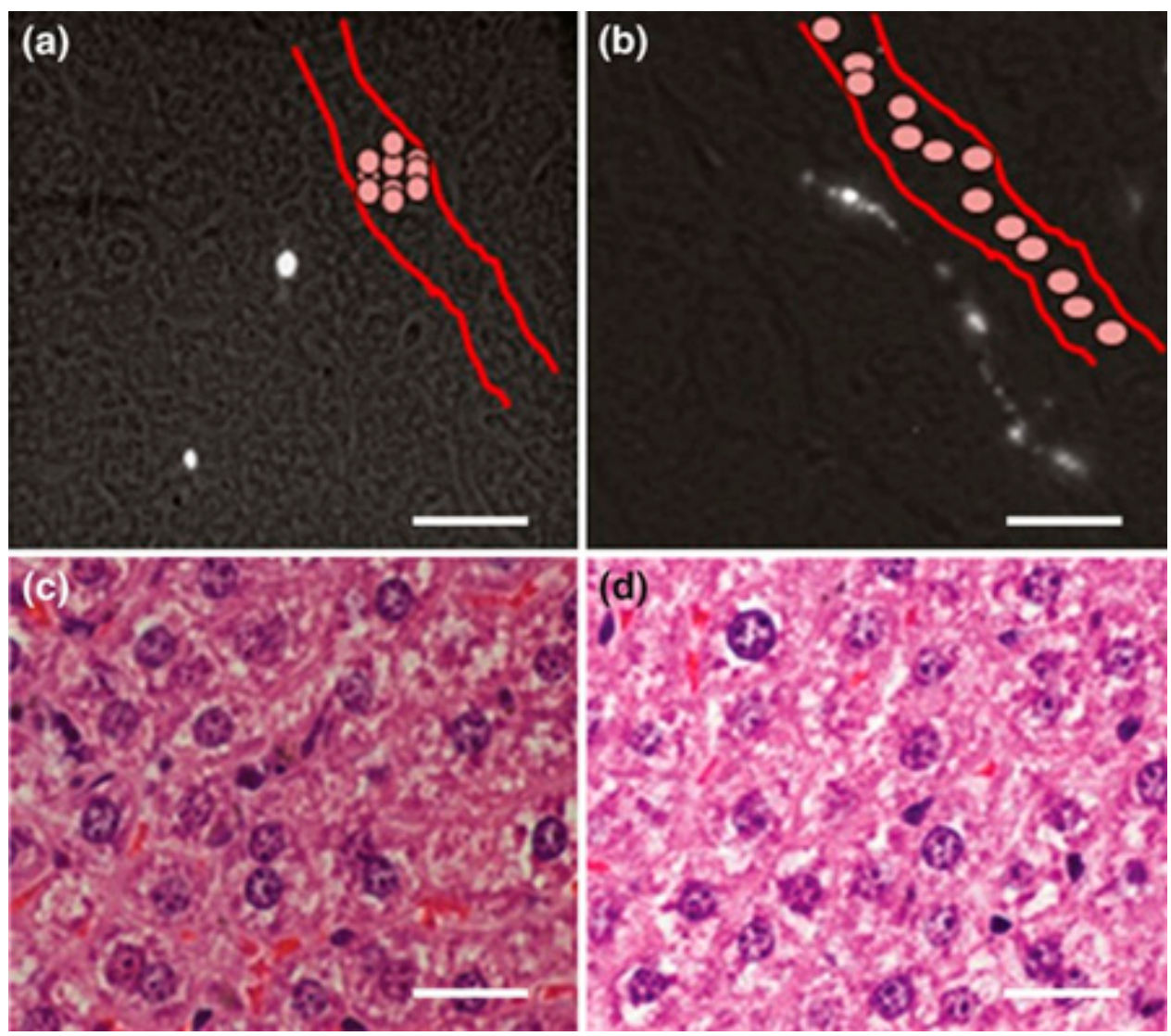

Figure 7. Fluorescence emission from mice liver samples after $24 \mathrm{~h}$ injection period with (a) bare, and (b) poly(ethylene glycol- $b$ poly(acrylic acid)c (PEG- $b$-PAAc)-modified $\mathrm{Er}^{3+}: \mathrm{Y}_{2} \mathrm{O}_{3}$ nanoparticles $(250 \mathrm{~nm}) ;(\mathbf{c}, \mathbf{d})$ bright-field images of bare and PEG-b-PAAc-modified samples, respectively (scale bar: $25 \mu \mathrm{m})$. (Reprinted with permission from Reference [142]. Copyright@ 2013 American Chemical Society). 
The NIR fluorescence area in Figure $7 a, b$ denotes the distribution of $\mathrm{Er}^{3+}: \mathrm{Y}_{2} \mathrm{O}_{3}$ in the blood vessels of mice liver. This observation shows that PEG-b-PAAc modification significantly reduced the agglomeration of $\mathrm{Er}^{3+}: \mathrm{Y}_{2} \mathrm{O}_{3}$ under physiological conditions. Further investigations by inductively coupled plasma mass spectrometry, including the quantification of $\mathrm{Er}^{3+}: \mathrm{Y}_{2} \mathrm{O}_{3}$ present in mice organs, are recently underway [142].

Near-infrared bioimaging (NIR) is a growing field in optical research. Because of the absence of strong scattering and color fading of phosphors, they could offer persistent color and perfect imaging. Trivalent-rare-earth ion-doped $\mathrm{Y}_{2} \mathrm{O}_{3}$ nanocrystals have been synthesized, and their photoluminescence properties have been studied under $980 \mathrm{~nm}$ laser diode excitation. The ratio of the intensity of green luminescence to that of red luminescence has decreased with an increase of concentration of $\mathrm{Yb}^{3+} \mathrm{Yb}^{3+}$ in $\mathrm{Er}^{3+} \mathrm{Er}^{3+}$ doped $\mathrm{Y}_{2} \mathrm{O}_{3}$ nanocrystals. Insufficient quantities of $\mathrm{Yb}^{3+}$ to $\mathrm{Er}^{3+}$ the bright red emission near $660 \mathrm{~nm}$ has been predominant due to the $4 \mathrm{~F}_{9} / 2-4 \mathrm{I}_{15} / 24 \mathrm{~F}_{9} / 2-4 \mathrm{I}_{15} / 2$ transition of $\mathrm{Er}^{3+}$. The primary color components are in these red, green, and blue emissions, from which a wide spectrum of colors, including white, would be produced by appropriately mixing them. In fluorescence bioimaging, yttrium oxide-derived, rare-earth-doped ceramic NPs were used for biological imaging targets.

Nowadays, the delivery of liposome encapsulating ceramic phosphorus has been widely employed [143] and used as a drug delivery system. Jia et al. [110] have synthesized and reported a similar-sized sphere derived from melamine-formaldehyde (MF) templates, followed by calcination. This could be converted into a crystalline $\mathrm{Y}_{2} \mathrm{O}_{3}$ precursor into $\mathrm{Y}_{2} \mathrm{O}_{3}$ during annealing. Moreover, SEM and TEM studies supported those $\mathrm{Y}_{2} \mathrm{O}_{3}$ hollow particles inherited a spherical shape and a better distribution of MF templates. The shell of hollow spheres was filled with a large number of nanoparticles of similar size. Furthermore, a lanthanide activator ion $\mathrm{Ln}^{3+}$ doped with $\mathrm{Y}_{2} \mathrm{O}_{3}$ hollow nanoparticle was found to be bright and offered sensitive up- and down-conversion luminescence ability with diverse colors sourced from activator ions at $980 \mathrm{~nm}$ light vibration (Figure 8). This is used for targeting in the field of advanced flat panel display and drug delivery systems.
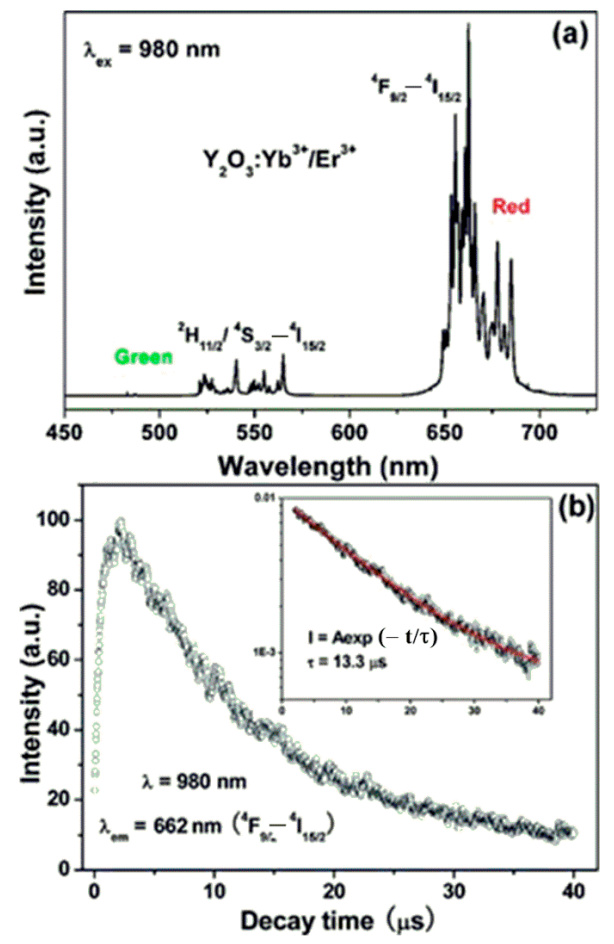

Figure 8. (a) Up-conversion (UC) luminescence spectra of $\mathrm{Y}_{2} \mathrm{O}_{3}: 10 \% \mathrm{Yb}^{3+}, 1 \% \mathrm{Er}^{3+}$ hollow spheres under $980 \mathrm{~nm}$ light excitation, and (b) the temporal behavior of $\mathrm{Er}^{3+}$ in $\mathrm{Y}_{2} \mathrm{O}_{3}: 10 \% \mathrm{Yb}^{3+}, 1 \% \mathrm{Er}^{3+}$ sample. 
Inset is the luminescence decay curve of $\mathrm{Er}^{3+}$ (662 nm, 4 F9/2-4 I15/2). (Reprinted with permission from Ref. [110]. Copyright@ 2013 American Chemical Society).

\section{Practical Applications and Future Research Perspectives}

Despite the considerable progress made in recent years in the development of rareearth-based nanomaterials for biotechnological applications, which is reflected in a large number of metal-organic frameworks and NPs accessible with many different compositions, morphology, size, properties, and applications, some challenges and improvements have yet to be addressed before these systems can be used clinically. The development of multifunctional systems is certainly one of the most useful research focuses on the design of rare-earth-based nanomaterials for biotechnological applications. In fact, numerous luminescent rare-earth based nanomaterials are developed to provide at least one additional functionality, either as MRI thus providing a clear diagnosis by combining the advantages of each modality. Rare-earth-based nanomaterials can act as very efficient contrast agents in a variety of applications. Medical imaging methods and provide a wide range of options for modern cancer therapy. $\mathrm{Y}_{2} \mathrm{O}_{3}$ NPs is an air-stable, solid substance white in color. It is used in the field of material sciences to make phosphors that are used in imparting the red color of the picture tubes in televisions. Another major use of the yttrium oxide nanoparticles is in inorganic synthesis. In the field of materials science, these particles find a number of applications such as imparting color to the television picture tubes. It is also used in the making of plasma and flat panel displays. Yttrium iron garnets are derived from yttrium oxide are used as powerful microwave filters. $\mathrm{Y}_{2} \mathrm{O}_{3}$ is a vital starting point in the inorganic synthesis of compounds. The property of red light emission is used in making fluorescent lamps. They are also used as additives in the coatings used in high-temperature applications, paints, and plastics for guarding against UV degradation and also in making permanent magnets and in ultrafast sensors that are used in g-ray and $\mathrm{X}$-rays. Some of the other applications include additives in steel, non-ferrous alloys, and iron. $\mathrm{Y}_{2} \mathrm{O}_{3} \mathrm{NPs}$ are an excellent host material for rare earth metals and have high luminescence efficiency providing a potential application in photodynamic therapy and biological imaging.

\section{Conclusions}

Nanoparticles research is at the forefront because of its enormous technological potential. As a leading nanomaterial in targeted drug delivery and nanomedicine, precise sizes with specified surface characteristics are the key requirements for nanoparticle synthesis. $\mathrm{Y}_{2} \mathrm{O}_{3}$ nanoparticles play a vital role in the biomedical field. This review discussed their physicochemical properties, such as their size, shape, structure, and chemical nature that influence their biomedical applications. Their unique properties, such as higher dielectric constant and good thermal stability, when compared with other inorganic nanoparticles, were highlighted. The antioxidant and antimicrobial nature of the yttrium oxide nanoparticles was highly debatable while being applied for cancer therapies. The biomedical application of yttrium oxides, like drug delivery, biosensors, bioimaging, fluorescence imaging, and anticancer therapies, were highlighted. This review provides a good platform for further yttrium oxide nanoparticles research, particularly in the field of biomedical applications.

Author Contributions: G.R., L.M., T.B., W.W., S.W., and X.Z., writing—original draft preparation; T.G., N.G., M.R., M.A.S., I.-M.C. and M.T. writing-review and editing. All authors have read and agreed to the published version of the manuscript.

Funding: This research received no external funding.

Institutional Review Board Statement: Not applicable.

Informed Consent Statement: Not applicable.

Data Availability Statement: Data is contained within the article. 
Acknowledgments: This paper was supported by the KU Research Professor Program of Konkuk University, Seoul, South Korea.

Conflicts of Interest: The authors declare no conflict of interest.

\section{References}

1. Thakur, N.; Manna, P.; Das, J. Synthesis and biomedical applications of nanoceria, a redox active nanoparticle. J. Nanobiotechnol. 2019, 17, 84. [CrossRef] [PubMed]

2. Wang, E.C.; Wang, A.Z. Nanoparticles and their applications in cell and molecular biology. Integr. Biol. 2014, 6, 9-26. [CrossRef] [PubMed]

3. U.S. Geological Survey. Mineral Commodity Summaries; U.S. Geological Survey: Reston, VA, USA, 2019.

4. Dasgupta, N.; Krishnamoorthy, R.; Jacob, K.T. Glycol—nitrate combustion synthesis of fine sinter-active yttria. Int. J. Inorg. Mater. 2001, 3, 143-149. [CrossRef]

5. Balakrishnan, S.; Ananthasivan, K.; Hari Kumar, K.C. Studies on the synthesis of nanocrystalline yttria powder by oxalate deagglomeration and its sintering behavior. Ceram. Int. 2015, 41, 5270-5280. [CrossRef]

6. Kwo, J.; Hong, M.; Kortan, A.R.; Queeney, L.; Chabal, Y.J.; Mannaerts, J.P.; Boone, T.; Krajewski, J.J.; Sergent, A.M.; Rosamilia, J.M. High $\varepsilon$ gate dielectrics $\mathrm{Gd}_{2} \mathrm{O}_{3}$ and $\mathrm{Y}_{2} \mathrm{O}_{3}$ for silicon. Appl. Phys. Lett. 2000, 77, 130-132. [CrossRef]

7. Rastogi, A.C.; Desu, S.B. Current conduction and dielectric behavior of high $\mathrm{k}-\mathrm{Y}_{2} \mathrm{O}_{3}$ films integrated with Si using chemical vapor deposition as a gate dielectric for metal-oxide semiconductor devices. J. Electroceram. 2004, 13, 121-127. [CrossRef]

8. Rastogi, A.C.; Sharma, N. Interfacial charge trapping in extrinsic $\mathrm{Y}_{2} \mathrm{O}_{3} / \mathrm{SiO}_{2}$ bilayer gate dielectric based MIS devices on Si (100). Semicond. Sci. Technol. 2001, 16, 641-650. [CrossRef]

9. $\mathrm{Wu}, \mathrm{C} .-\mathrm{H} . ;$ Chen, J.-Z. Ultrafast atmospheric-pressure-plasma-jet processed conductive plasma-resistant $\mathrm{Y} 2 \mathrm{O} 3 /$ carbon-nanotube nanocomposite. J. Alloy. Compd. 2015, 651, 357-362. [CrossRef]

10. Xu, Y.-N.; Gu, Z.-q.; Ching, W.Y. Electronic, structural, and optical properties of crystalline yttria. Phys. Rev. B 1997, 56, 14993-15000. [CrossRef]

11. Kenyon, A.J. Recent developments in rare-earth-doped materials for optoelectronics. Prog. Quant. Electron. 2002, 26, 225-284. [CrossRef]

12. Wen, W.; Yang, X.; Wang, X.; Shu, L.G.H. Improved electrochemical performance of the spherical LiNi0.5Mn1.5O4 particles modified by nano- $\mathrm{Y}_{2} \mathrm{O}_{3}$ coating. J. Solid. State. Electrochem. 2015, 19, 1235-1246. [CrossRef]

13. Wu, F.; Wang, M.; Su, Y.; Chen, S. Surface modification of LiCo1/3Ni1/3Mn1/3O $\mathrm{O}_{2}$ with $\mathrm{Y}_{2} \mathrm{O}_{3}$ for lithium-ion battery. J. Power Sources 2009, 189, 743-747. [CrossRef]

14. Kong, J.; Tang, D.Y.; Zhao, B.; Lu, J.; Ueda, K.; Yagi, H.; Yanagitani, T. 9.2-W diodeeendepumped Yb: $\mathrm{Y}_{2} \mathrm{O}_{3}$ ceramic laser. Appl. Phys. Lett. 2005, 86, 161116. [CrossRef]

15. Baytak, A.K.; Teker, T.; Duzmen, S.; Aslanoglu, M. A composite material based onnanoparticles of yttrium (III) oxide for the selective and sensitive electrochemical determination of acetaminophen. Mater. Sci. Eng. C 2016, 66, 278-284. [CrossRef] [PubMed]

16. Khajelakzay, M.; Razavi, R.S.; Barekat, M.; Naderi, M. Synthesis of yttria nanopowders by two precipitation methods and investigation of synthesis conditions. Int. J. Appl. Ceram. Technol. 2016, 13, 209. [CrossRef]

17. Kannan, S.K.; Sundararajan, M. Biosynthesis of yttrium oxide nanoparticles using Acalypha indica leaf extract. Bull. Mat. Sci. 2015, 38, 945-950. [CrossRef]

18. Andelman, T.; Gordonov, S.; Busto, G.; Moghe, P.V.; Riman, R.E. Synthesis and cytotoxicity of $\mathrm{Y}_{2} \mathrm{O}_{3}$ nanoparticles of various morphologies nanoscale. Res. Lett. 2010, 5, 263.

19. Bondar, V.V. Structure and luminescence properties of individual and multi-layer thin-film systems based on oxide phosphors. Mater. Sci. Eng. B 2000, 69-70, 505-509. [CrossRef]

20. Tilloca, G. Synthesis of ultrafine pure and yttria-stabilized hafnia by solid-state reaction at relatively low temperature. J. Mater. Sci. 1995, 30, 1884-1889. [CrossRef]

21. De, G.; Qin, W.; Zhang, J.; Zhao, D.; Zhang, J. Bright-green upconversion emission of hexagonal LaF $\mathrm{L}_{3} \mathrm{Yb}^{3+}, \mathrm{Er}^{3+}$ nanocrystals. Chem. Lett. 2005, 34, 914-991. [CrossRef]

22. Deng, C.; Wang, Y.; Zhang, Y.; Gao, J. Effects of Y2O3 upon mechanical properties of laser coating. Chin. Opt. Lett. 2005, 3, 530-532.

23. Verhiest, K.; Almazouzi, A.; Wispelaere, N.; Petrov, R.; Claessens, S. Development of oxides dispersion strengthened steels for high-temperature nuclear reactor applications. J. Nucl. Mater. 2009, 385, 308. [CrossRef]

24. Wang, Z.C.; Kim, K.B. Fabrication of YSZ thin films from suspension by electrostatic spray deposition. Mater. Lett. 2008, 62, 425. [CrossRef]

25. Salata, O.V. Applications of nanoparticles in biology and medicine. J. Nanobiotechnol. 2004, 2, 3. [CrossRef] [PubMed]

26. Tiwari, D.K.; Behari, J.; Sen, P. Application of nanoparticles in wastewater treatment. World. Appl. Sci. J. 2008, 47, 3931-3946.

27. Ghodake, G.; Shinde, S.; Saratale, G.D.; Kadam, A.; Saratale, R.G.; Kim, D.Y. Water purification filter prepared by layer-by-layer assembly of paper filter and polypropylene-polyethylene woven fabrics decorated with silver nanoparticles. Fibers Polym. 2020, 21, 751-761. [CrossRef] 
28. Saratale, G.D.; Saratale, R.G.; Cho, S.K.; Ghodake, G.; Bharagava, R.M.; Park, Y.; Mulla, S.I.; Kim, D.S.; Kadam, A.; Nair, S.; et al. Investigation of photocatalytic degradation of reactive textile dyes by Portulaca oleracea-functionalized silver nanocomposites and exploration of their antibacterial and antidiabetic potentials. J. Alloys Compd. 2020, 833, 155083. [CrossRef]

29. Puzyn, T.; Rasulev, B.; Gajewicz, A.; Hu, X.; Dasari, T.P.; Michalkova, A. Using nano-QSAR to predict the cytotoxicity of metal oxide nanoparticles. Nat. Nanotechnol. 2011, 6, 175-178. [CrossRef]

30. Wang, Y.C.; Yue, S.T.; Li, D.Q.; Jin, M.J.; Li, C.Z. Solvent extraction of scandium (III), yttrium (III), lanthanides (III) and divalent metal ion with sec-nonyl phenoxy acetic acid. Solvent Extr. Ion Exch. 2002, 20, 701-706. [CrossRef]

31. Lakshminarasappa, B.N.; Shivaramu, N.J.; Nagabhushana, K.R.; Singh, F. Synthesis characterization and luminescence studies of $100 \mathrm{MeV}$ Si8+ ion irradiated sol-gel derived nanocrystalline $\mathrm{Y}_{2} \mathrm{O}_{3}$. Nucl. Inst. Methods. Phys. Res. 2014, 329, 40-47. [CrossRef]

32. Nunes, D.; Pimentel, A.; Matias, M.; Freire, T.; Araújo, A.; Silva, F.; Gaspar, P.; Garcia, S.; Carvalho, P.A.; Fortunato, E.; et al. Tailoring upconversion and morphology of $\mathrm{Yb} /$ Eu doped $\mathrm{Y}_{2} \mathrm{O}_{3}$ nanostructures by acid composition mediation. Nanomaterials 2019, 9, 234. [CrossRef]

33. Lin, L.L.; Starostin, S.A.; Li, S.; Khan, S.A.; Hessel, V. Synthesis of yttrium oxide nanoparticles via a facile microplasma-assisted process. Chem. Eng. Sci. 2018, 178, 157-166. [CrossRef]

34. Chen, S.; Lin, J.; Wu, J. Facile synthesis of $\mathrm{Y}_{2} \mathrm{O}_{3}:$ Dy ${ }^{3+}$ nanorods and its application in dye-sensitized solar cells. Appl. Surf. Sci. 2014, 293, 202-206. [CrossRef]

35. Zhai, Y.; Yao, Z.; Ding, S.; Qiu, M.; Zhai, J. Synthesis and characterization of $\mathrm{Y}_{2} \mathrm{O}_{3}$ : Eu nanopowder via EDTA complexing sol-gel process. Mat. Lett. 2003, 57, 2901-2906.

36. Rebeca, M.V.; Margarita, G.H.; Arturo, L.M.; Perla, Y.L.C.; Ángel, J.M.R.; Hiram, I.B.C. Sol-gel synthesis and antioxidant properties of yttrium oxide nanocrystallites incorporating P-123. Materials 2014, 7, 6768-6778.

37. Mariano-Torres, J.A.; López-Marure, A.; García-Hernández, M.; Basurto-Islas, G.; Ángel Domínguez-Sánchez, M. Synthesis and characterization of glycerol citrate polymer and yttrium oxide nanoparticles as a potential antibacterial material. Mat. Transact. 2018, 59, 1915-1919. [CrossRef]

38. Chen, K.; Peng, J.; Srinivasakannan, C.; Yin, S.; Guo, S.; Zhang, L. Effect of temperature on the preparation of yttrium oxide in microwave field. J. Alloys. Compd. 2018, 742, 13-19. [CrossRef]

39. Nagajyothi, P.C.; Pandurangan, M.; Veerappan, M.; Kim, D.W.; Sreekanth, T.V.M.; Shim, J. Green synthesis, characterization and anticancer activity of yttrium oxide nanoparticles. Mat. Lett. 2018, 216, 58-62. [CrossRef]

40. Lellouche, J.; Friedman, A.; Gedanken, A.; Banin, E. Antibacterial and antibiofilm properties of yttrium fluoride nanoparticles. Int. J. Nanomed. 2012, 7, 5611-5624.

41. Huang, Z.; Sun, X.; Xiu, Z.; Chen, S.; Tsai, C.T. Precipitation synthesis and sintering of yttria nanopowders. Mat. Lett. 2004, 58, 2137-2142. [CrossRef]

42. Lide, D.R. CRC Handbook of Chemistry and Physics, 84th ed.; CRC Press: Boca Raton, FL, USA, 2003; Volume 53, p. 2616.

43. Tomaszewski, H.; Weglarz, H.; DeGryse, R. Crystallization of yttria under hydrothermal conditions. J. Eur. Ceram. Soc. 1997, 17, 403-406. [CrossRef]

44. Zhang, L.; Hou, X.; Liu, M.; Lv, Y.; Hou, X. Controllable synthesis of $\mathrm{Y}_{2} \mathrm{O}_{3}$ microstructures for application in cataluminescence gas sensing. Chem. Eur. J. 2011, 17, 7105-7111. [CrossRef] [PubMed]

45. $\mathrm{Hu}$, C.Q.; Gao, Z.H. Synthesis of $\mathrm{Y}_{2} \mathrm{O}_{3}$ with nestlike structures. J. Mater. Sci. 2006, 41, 6126. [CrossRef]

46. Li, N.; Yanagisawa, K. Controlling the morphology of yttrium oxide through different precursors synthesized by hydrothermal method. J. Solid. State. Chem. 2008, 181, 1738. [CrossRef]

47. Zhu, H.Y.; Ma, Y.Z.; Yang, H.B.; Zhu, P.F.; Du, J.B.; Ji, C.; Hou, D.B. Ultrastable structure and luminescence properties of $\mathrm{Y}_{2} \mathrm{O}_{3}$ nanotubes. Solid. State. Commun. 2010, 150, 1208. [CrossRef]

48. Tang, Q.; Liu, Z.P.; Li, S.; Zhang, S.Y.; Liu, X.M.; Qian, Y.T. Synthesis of yttrium hydroxide and oxide nanotubes. J. Cryst. Growth 2003, 259, 208. [CrossRef]

49. Li, Y.G.; Lin, X.Y.; Wang, Y.Z.; Luo, J.M.; Sun, W.L. Preparation, and characterization of porous yttrium oxide powders with high specific surface area. J. Rare Earths 2006, 24, 34. [CrossRef]

50. Lin, Y.-F.; Chen, J.-H.; Hsu, S.-H.; Chung, T.-W. Hydrothermal synthesis of lewis acid $\mathrm{Y}_{2} \mathrm{O}_{3}$ cubes and flowers for the removal of phospholipids from soybean oil. Cryst. Eng. Comm. 2013, 15, 6506. [CrossRef]

51. Liu, J.C.; $\mathrm{Wu}, \mathrm{B} . \mathrm{L}$. Effects of $\mathrm{Eu}_{2} \mathrm{O}_{3}$ addition on microstructure, grain-boundary cohesion and wear resistance of high-alumina ceramics. J. Alloy. Compd. 2014, 50, 49. [CrossRef]

52. Kruk, A.; Wajler, A.; Mrozek, M.; Zych, L.; Gawlik, W.; Brylewski, T. Transparent yttrium oxide ceramics as potential optical isolator materials. Opt. Appl. 2015, 45, 585.

53. Foo, Y.T.; Abdullah, A.Z.; Horri, B.A.; Salamatinia, B. Synthesis and characterization of $\mathrm{Y}_{2} \mathrm{O}_{3}$ using ammonia oxalate as a precipitant in distillate pack co-precipitation process. Ceram. Int. 2018, 44, 18693-18702. [CrossRef]

54. Bhavani, G.; Ganesan, S. Structural, morphological and optical study of bismuth and zinc co-doped yttrium oxide prepared by solvothermal and wet chemical method. Acta. Phys. Pol. 2016, 130. [CrossRef]

55. Su, T.M.; Qin, Z.Z.; Ji, H.B.; Jiang, Y.X. Preparation, characterization, and activity of $\mathrm{Y}_{2} \mathrm{O}_{3}$-ZnO complex oxides for the photodegradation of 2,4-dinitrophenol. Int. J. Photoenergy 2014, 794057. [CrossRef]

56. Zhou, B.Z.; Zhou, G.H.; An, L.; Zhang, F.; Zhang, G.J.; Wang, S.H. Morphology-controlled synthesis of yttrium hafnate by oxalate co-precipitation method and the growth mechanism. J. Alloy. Compd. 2009, 481, 434-437. [CrossRef] 
57. Kabir, M.; Ghahari, M.; Afarani, M.S. Co-precipitation synthesis of nano $\mathrm{Y}_{2} \mathrm{O}_{3}: \mathrm{Eu}^{3+}$ with different morphologies and its photoluminescence properties. Ceram. Int. 2014, 40, 10877-10885. [CrossRef]

58. Srinivasan, R.; Yogamalar, R.; Chandra, B.A. Structural and optical studies of yttrium oxide nanoparticles synthesized by co-precipitation method. Mat. Res. Bull. 2010, 45, 1165-1170. [CrossRef]

59. Wen, L.; Sun, X.; Lu, Q.; Xu, G.; Hu, X. Synthesis of yttria nanopowders for transparent yttria ceramics. Opt. Mat. 2006, 29, 239-245. [CrossRef]

60. Giesche, H.; Matijevic, E. Preparation, characterization, and sinterability of well-defined silica/yttria powders. J. Mater. Res. 1994, 9, 436. [CrossRef]

61. Sordelet, D.J.; Akinc, M.; Panchula, M.L.; Han, Y.; Han, M.H. Synthesis of yttrium aluminum garnet precursor powders by homogeneous precipitation. J. Eur. Ceram. Soc. 1994, 14, 123. [CrossRef]

62. Wang, J.; Zhang, Z.; Guo, X.; Zhao, J.; Chen, H.; Yang, X. High quality thin film phosphors of $\mathrm{Y}_{2} \mathrm{O}_{3}$ : Eu ${ }^{3+}$ deposited via chemical bath deposition. J. Rare Earths 2010, 28, 684-687. [CrossRef]

63. Li, Y.H.; Zhang, Y.M.; Hong, G.Y.; Yu, Y.N. Upconversion luminescence of $\mathrm{Y}_{2} \mathrm{O}_{3}: \mathrm{Er}^{3+}, \mathrm{Yb}^{3+}$ nanoparticles prepared by a homogeneous precipitation method. J. Rare. Earths 2008, 26, 450. [CrossRef]

64. Bhagat, D.S.; Katariya, M.V.; Patil, C.S.; Deshmukh, S.U.; Shisodia, S.U.; Pandule, S.S.; Pawar, R.P. Yttrium oxide: A highly efficient catalyst for the synthesis of pyrano[2,3-d]pyrimidine derivatives in aqueous methanol media. Eur. Chem. Bull. 2015, 4, 450-453.

65. Lin, C.; Zhang, C.; Lin, J. Sol-gel derived $\mathrm{Y}_{2} \mathrm{O}_{3}$ as an efficient bluish-white phosphor without metal activator ions. J. Lumin. 2009, 129, 1469-1474. [CrossRef]

66. Pechini, M.P. Method of Preparing Lead and Alkaline Earth Titanates and Niobates and Coating Method Using the Same to Form a Capacitor. U.S. Patent 3330697, 11 July 1967.

67. Simoes, A.Z.; Ries, A.; Riccardi, C.S.; Gonzalez, A.H.; Zaghete, M.A.; Stojanovic, B.D.; Cilense, M.; Varela, J.A. Effect of magnesium on structure and properties of $\mathrm{LiNbO}_{3}$ prepared from polymeric precursors. Mater. Lett. 2004, 58, 2537-2540. [CrossRef]

68. Zaki, T.; Kabel, K.I.; Hassan, H. Using modified Pechini method to synthesize a- $\mathrm{Al}_{2} \mathrm{O}_{3}$ nanoparticles of high surface area. Ceram. Int. 2012, 38, 4861-4866. [CrossRef]

69. Tao, X.; Chen, X.; Xia, Y.; Huang, H.; Gan, Y.; Wu, R.; Chen, F.; Zhang, W. Highly mesoporous carbon foams synthesized by a facile, cost-effective and template-free Pechini method for advanced lithium-sulfur batteries. J. Mater. Chem. A 2013, 1, 3295-3301. [CrossRef]

70. Kolesnikov, I.E.; Povolotskiy, A.V.; Mamonova, D.V.; Lahderanta, Z.; Manshinaa, A.A.; Mikhailov, M.D. Photoluminescence properties of $\mathrm{Eu}^{3+}$ ions in yttrium oxide nanoparticles: Defect vs. normal sites. RSC Adv. 2016, 6, 76533. [CrossRef]

71. Guo, B.; Yim, H.; Hwang, W.; Nowell, M.; Luo, Z. Crystalline phase of $\mathrm{Y}_{2} \mathrm{O}_{3}$ :Eu particles generated in a substrate-free flame process. Particuology 2011, 9, 24-31. [CrossRef]

72. Strobel, R.; Pratsinis, S.E. Flame aerosol synthesis of smart nanostructured materials. J. Mat. Chem. 2007, 17, 4743-4756. [CrossRef]

73. Kang, Y.C.; Seo, D.J.; Park, S.B.; Park, H.D. Morphological and optical characteristics of $\mathrm{Y}_{2} \mathrm{O}_{3}$ : Eu phosphor particles prepared by flame spray pyrolysis. Jpn. J. Appl. Phys. 2001, 40, 4083-4086. [CrossRef]

74. Cho, S.C.; Uhm, H.S.; Bang, C.U.; Lee, D.K.; Han, C.S. Production of nanocrystalline $\mathrm{Y}_{2} \mathrm{O}_{3}$ : Eu powder by microwave plasma-torch and its characterization. Thin Solid Films 2009, 517, 4052-4055. [CrossRef]

75. Kubrin, R.; Bauhofer, W. Influence of polymeric additives on morphology and performance of $\mathrm{Y}_{2} \mathrm{O}_{3}$ :Eu phosphor synthesized by flame-assisted spray pyrolysis. J. Lumin. 2009, 129, 1060-1066. [CrossRef]

76. Dosev, D.; Guo, B.; Kennedy, I.M. Photoluminescence of $\mathrm{Eu}^{3+}: \mathrm{Y}_{2} \mathrm{O}_{3}$ as an indication of crystal structure and particle size in nanoparticles synthesized by flame spray pyrolysis. J. Aerosol Sci. 2006, 37, 402-412. [CrossRef]

77. Seo, D.J.; Kang, Y.C.; Park, S.B. The synthesis of $(\mathrm{Y} 1-\mathrm{xGdx})_{2} \mathrm{O}_{3}$ :Eu phosphor particles by flame spray pyrolysis with LiCl flux. Appl. Phys. A 2003, 77, 659-663. [CrossRef]

78. Huo, D.; Sun, X.D.; Xiu, Z.M.; Li, X.D. Influence of processing conditions on morphologies and sinterability of ultrafine $\mathrm{Y}_{2} \mathrm{O}_{3}$ powders. J. Chin. Soc. Rare Earths 2007, 25, 566.

79. Hong, G.Y. Syntheses and assemblies of rare earth nanomaterials. J. Chin. Soc. Rare Earths 2006, $24,641$.

80. Chen, J.; Peng, R.; Chen, X. Hydrophobic interaction membrane chromatography for bioseparation and responsive polymer ligands involved. Front. Mater. Sci. 2017, 11, 197-214. [CrossRef]

81. Saratal, G.D.; Kim, H.Y.; Saratalec, R.G.; Kim, D.S. Liquid-liquid extraction of yttrium from the sulfate leach liquor of waste fluorescent lamp powder: Process parameters and analysis. Miner. Eng. 2020, 152, 106341. [CrossRef]

82. Saratale, R.G.; Kim, H.Y.; Park, Y.; Shin, H.S.; Ghodake, G.; Bharagava, R.N.; Mulla, S.I.; Kim, D.S.; Saratale, G.D. Hydrometallurgical process for the recovery of yttrium from spent fluorescent lamp: Leaching and crystallization experiments. J. Clean. Prod. 2020, 261, 121009. [CrossRef]

83. Basavegowda, N.; Mishra, K.; Thombal, R.S.; Kaliraj, K.; Lee, Y.R. Sonochemical green synthesis of yttrium oxide $\left(\mathrm{Y}_{2} \mathrm{O}_{3}\right)$ nanoparticles as a novel heterogeneous catalyst for the construction of biologically interesting 1,3. Catal. Lett. 2017, 147, 2630-2639. [CrossRef]

84. Saratale, R.G.; Karuppusamy, I.; Saratale, G.D.; Pugazhendhi, A.; Kumar, G.; Park, Y.; Ghodake, G.S.; Bharagava, R.N.; Banu, J.R.; Shin, H.S. A comprehensive review on green nanomaterials using biological systems: Recent perception and their future applications. Colloids Surf. B Biointerfaces 2018, 170, 20-35. [CrossRef] [PubMed] 
85. Saratale, R.G.; Ghodake, G.S.; Shinde, S.K.; Cho, S.K.; Saratale, G.D.; Pugazhendhi, A.; Bharagava, R.N. Photocatalytic activity of $\mathrm{CuO} / \mathrm{Cu}(\mathrm{OH})_{2}$ nanostructures in the degradation of Reactive Green 19A and textile effluent, phytotoxicity studies and their biogenic properties (antibacterial and anticancer). J. Environ. Manag. 2018, 223, 1086-1097. [CrossRef] [PubMed]

86. Saratale, R.G.; Shin, H.S.; Kumar, G.; Benelli, G.; Ghodake, G.S.; Jiang, Y.Y.; Kim, D.S.; Saratale, G.D. Exploiting fruit byproducts for eco-friendly nanosynthesis: Citrus $\times$ clementina peel extract mediated fabrication of silver nanoparticles with high efficacy against microbial pathogens and rat glial tumor C6 cells. Environ. Sci. Pollut. Res. Int. 2018, 25, 10250-10263. [CrossRef] [PubMed]

87. Venugopal, J.R.; Ramakrishna, S. Nanotechnology: 21st-century revolution in restorative healthcare. Nanomedicine 2016, 11, 1511-1513. [CrossRef]

88. Jha, R.K.; Jha, P.K.; Chaudhury, K.; Rana, S.V.; Guha, S.K. An emerging interface between life science and nanotechnology: Present status and prospects of reproductive healthcare aided by nano-biotechnology. Nano Rev. 2014, 5, 22762. [CrossRef]

89. Yamamoto, O.; Komatsu, M.; Sawai, J.; Nakagawa, Z. Effect of lattice constant of zinc oxide on antibacterial characteristics. J. Mater. Sci. Mater. Med. 2004, 15, 847-851. [CrossRef]

90. Ischenko, V.; Polarz, A.; Grote, D.; Stavarache, V.; Fink, K.; Driess, M. Zinc oxide nanoparticles with defects. Adv. Funct. Mater. 2005, 15, 1945. [CrossRef]

91. Slate, A.J.; Shalamanova, L.; Akhidime, I.D.; Whitehead, K.A. Rhenium and yttrium ions as antimicrobial agents against multidrug-resistant Klebsiella pneumoniae and Acinetobacter baumannii biofilms. Lett. Appl. Microbiol. 2019, 69, 168-174. [CrossRef]

92. Wang, Y.; Yang, H.; Xue, X. Synergistic antibacterial activity of $\mathrm{TiO}_{2}$ co-doped with zinc and yttrium. Vacuum 2014, 107, 28-32. [CrossRef]

93. Asiry, M.A.; Alshahrani, I.; Alqahtani, N.D.; Durgesh, B.H. Efficacy of yttrium (iii) fluoride nanoparticles in orthodontic bonding. J. Nanosci. Nanotechnol. 2019, 19, 1105-1110. [CrossRef]

94. de Soet, J.J.; de Graaff, J. Microbiology of carious lesions. Dent. Update 1998, 25, 319.

95. Arsiyaa, F.; Sayadia, M.H.; Sobhani, S. Green synthesis of palladium nanoparticles using Chlorella vulgaris. Mater. Lett. 2017, 186, 113-115. [CrossRef]

96. Hosseini, A.; Baeeri, M.; Rahimifard, M.; Navaei-Nigjeh, M.; Mohammadirad, A.; Pourkhalili, N.; Hassani, S.; Kamali, M. Antiapoptotic effects of cerium oxide and yttrium oxide nanoparticles in isolated rat pancreatic islets. Hum. Exp. Toxicol. 2013, 32, 544. [CrossRef]

97. Perez, J.M.; Asati, A.; Nath, S.; Kaittanis, C. Synthesis of biocompatible dextran-coated nanoceria with pH-dependent antioxidant properties. Small 2008, 4, 552-556. [CrossRef]

98. Sayour, H.; Kassem, S.; Canfarotta, F.; Czulak, J.; Mohamed, M.; Piletsky, S. Biocompatibility and biodistribution of surfacemodified yttrium oxide nanoparticles for potential theranostic applications. Environ. Sci. Pollut. Res. Int. 2020, 16, 19095-19107. [CrossRef]

99. Chang, Y.; Liu, B.; Huang, Z.; Liu, Y.; Liu, M.; Liu, J. Yttrium oxide as a strongly adsorbing but nonquenching surface for DNA oligonucleotides. Langmuir 2020, 36, 1034-1042. [CrossRef]

100. Song, X.; Shang, P.; Sun, Z.; Lu, M.; You, G.; Yan, S.; Chen, G.; Zhou, H. Therapeutic effect of yttrium oxide nanoparticles for the treatment of fulminant hepatic failure. Nanomedicine 2019, 14, 2519-2533. [CrossRef]

101. Martin, P.; Leibovich, S.J. Inflammatory cells during wound repair: The good, the bad and the ugly. Trends. Cell. Biol. 2005, 15, 599-607. [CrossRef]

102. Memisogullari, R.; Taysi, S.; Bakan, E. Antioxidant status and lipid peroxidation in type II diabetes mellitus. Cell. Biochem. Funct. 2003, 21, 291. [CrossRef]

103. Maritim, A.C.; Sanders, R.A.; Watkins, J.B. Diabetes, oxidative stress, and antioxidants: A review. J. Biochem. Mol. Toxicol. 2003, 17, 24. [CrossRef]

104. Douki, T.; Cadet, J. Peroxynitrite mediated oxidation of purine bases of nucleosides and isolated DNA. Free Radic. Res. 1996, $24,369$. [CrossRef]

105. Mohammad, G.; Mishra, V.K.; Pandey, H.P. Antioxidant properties of some nanoparticle may enhance wound healing in T2DM patient. Digest J. Nanomater. Biostruct. 2008, 3, 159-162.

106. Warheit, D.B. Nanoparticles: Health impacts? Mater. Today 2004, 72, 32-35. [CrossRef]

107. Aglan, H.A.; Mabrouk, M.; Aly, R.M.; Beherei, H.H.; Ahmed, H.H. Harnessing the antioxidant property of cerium and yttrium oxide nanoparticles to enhance mesenchymal stem cell proliferation. Asian J. Pharmaceut. Clin. Res. 2018, 11, 436-442. [CrossRef]

108. Gier, B.; Krippeit-Drews, P.; Sheiko, T.; Aguilar-Bryan, L.; Bryan, J.; Dufer, M. Suppression of KATP channel activity protects murine pancreatic beta cells against oxidative stress. J. Clin. Investig. 2009, 119, 3246-3256.

109. Schubert, D.; Dargusch, R.; Raitano, J.; Chan, S.-W. Cerium and yttrium oxide nanoparticles are neuroprotective. Biochem. Biophys. Res. Commun. 2006, 342, 86-91. [CrossRef]

110. Jia, G.; You, H.Y.; Huang, Y.; Yang, M.; Zhang, H. Facile synthesis and luminescence of uniform $\mathrm{Y}_{2} \mathrm{O}_{3}$ hollow spheres by a sacrificial template route. Inorg. Chem. 2010, 49, 7721-7725. [CrossRef]

111. Patra, J.K.; Das, G.; Fraceto, L.F.; Campos, E.V.R.; Rodriguez-Torres, M.D.P.; Acosta-Torres, L.L.S. Nano-based drug delivery systems: Recent developments and future prospects. J. Nanobiotech. 2018, 16, 71. [CrossRef]

112. D'amato, G. Urban air pollution and plant-derived respiratory allergy. Clin. Exp. Allergy 2000, 30, 628-636.

113. Soto, K.F.; Carrasco, A.; Powell, T.G.; Garza, K.M.; Murr, L.E. Comparative in vitro cytotoxicity assessment of some manufactured nanoparticulate materials characterized by transmission electron microscopy. J. Nanopart. Res. 2015, 7, 145-169. [CrossRef] 
114. Becker, S.; Soukup, J.M.; Gallagher, J.E. Differential particulate air pollution induced oxidant stress in human granulocytes, monocytes, and alveolar macrophages. Toxicol. In Vitro 2002, 16, 209-218. [CrossRef]

115. Ishige, K.; Schubert, D.; Sagara, Y. Flavonoids protect neuronal cells from oxidative stress by three distinct mechanisms. Free Radic. Biol. Med. 2001, 30, 433-446. [CrossRef]

116. Liu, Z.; Yu, L.; Wang, Q.; Tao, Y.; Yang, H. Effect of Eu, Tb codoping on the luminescent properties of $\mathrm{Y}_{2} \mathrm{O}_{3}$ nanorods. J. Lumin. 2011, 131, 12-16. [CrossRef]

117. Vu, N.; Anh, T.K.; Yi, G.C.; Strek, W. Photoluminescence and cathodoluminescence properties of $\mathrm{Y}_{2} \mathrm{O}_{3}$ : Eu nanophosphors prepared by combustion synthesis. J. Lumin. 2007, 122, 776-779. [CrossRef]

118. Leskela, M.; Ritala, M. Rare-earth oxide thin films as gate oxides in MOSFET transistors. J. Solid State Chem. 2003, 171, 170-174. [CrossRef]

119. Ohta, A.; Yamaoka, M.; Miyazaki, S. Photoelectron spectroscopy of ultrathin yttrium oxide films on Si(100). Microelectron. Eng. 2014, 72, 154-159. [CrossRef]

120. de Rouffignac, P.; Park, J.-S.; Gordon, R.G. Atomic layer deposition of $\mathrm{Y}_{2} \mathrm{O}_{3}$ thin films from yttrium tris(N,N'-diisopropylacetamidinate) and water. Chem. Mater. 2005, 17, 4808-4814. [CrossRef]

121. Rao, T.N.; Hussain, I.; Lee, J.E.; Kumar, A.; Koo, B.H. Enhanced thermal properties of zirconia nanoparticles and chitosan-based intumescent flame retardant coatings. Appl. Sci. 2019, 9, 3464. [CrossRef]

122. Ukare, R.S.; Kurzekar, R.R.; Zade, G.D.; Dhoble, S.J. Yttrium oxide as an engineering material. Int. J. Curr. Eng. Sci. Res. 2018, 5, 173-181.

123. den Engelsen, D.; Terry, G.I.; Harris, P.G.; Reip, F.; Silver, J. Photoluminescence, cathodoluminescence and micro-Raman investigations of monoclinic nanometre-sized $\mathrm{Y}_{2} \mathrm{O}_{3}$ and $\mathrm{Y}_{2} \mathrm{O}_{3}: \mathrm{Eu}^{3+}$. Mater. Chem. C 2016, 4, 8930-8938. [CrossRef]

124. Ray, S.; Pramanik, P.; Singha, A.; Roy, A. Optical properties of nanocrystalline. J. Appl. Phys. 2005, 97, 094312. [CrossRef]

125. Packiyaraj, P.; Thangadurai, P. Structural and photoluminescence studies of Eu ${ }^{3+}$ doped cubic $\mathrm{Y}_{2} \mathrm{O}_{3}$ nanophosphors. J. Lumin. 2014, 145, 997-1003. [CrossRef]

126. Dhanaraj, J.; Jagannathan, R.; Kutty, T.R.N.; Lu, C.H. Photoluminescence characteristics of $\mathrm{Y}_{2} \mathrm{O}_{3}$ :Eu ${ }^{3+}$ nanophosphors prepared using sol-gel thermolysis. J. Phys. Chem. B 2001, 105, 11098. [CrossRef]

127. Ali, A.G.; Dejene, B.F.; Swart, H.C. Synthesis and characterization of $\mathrm{Y}_{2} \mathrm{O}_{3}$ :Eu ${ }^{3+}$ phosphors using the Sol-Combustion method. Phys. B. 2014, 439, 181-184. [CrossRef]

128. Jin, Z.W.; Yoo, Y.Z.; Sekiguchi, T.; Chikyow, T.; Ofuchi, H.; Fujioka, H.; Oshima, M.; Koinuma, H. Blue and ultraviolet cathodoluminescence from Mn-doped epitaxial ZnO thin films. Appl. Phys. Lett. 2003, 83, 39. [CrossRef]

129. Emeline, A.; Kataeva, G.V.; Litke, A.S.; Rudakova, A.V.; Ryabchuk, V.K.; Serpone, N. Spectroscopic and photoluminescence studies of a wide band gap insulating material: Powdered and colloidal $\mathrm{ZrO}_{2}$ Sols. Langmuir 1998, 14, 5011. [CrossRef]

130. Green, W.H.; Le, K.P.; Grey, J.; Au, T.T.; Sailor, M. High-temperature photoluminescence in sol-gel silica-containing SiC/C nanostructures. J. Sci. 1997, 276, 1826.

131. Hayakawa, T.; Hiramitsu, A.; Nogami, M. White light emission from radical carbonyl-terminations in $\mathrm{Al}_{2} \mathrm{O}_{3}-\mathrm{SiO}_{2}$ porous glasses with high luminescence quantum efficiencies. Appl. Phys. Lett. 2003, 82, 2975. [CrossRef]

132. Niioka, T.; Furukawa, M.; Ichimiya, M.; Ashida, T.; Araki, M. Hashimoto. Multicolor cathodoluminescence microscopy for biological imaging with nanophosphors. Nanopart. Sci. Rep. 2016, 6, 25950.

133. Adam, J.; Metzger, W.; Koch, M.; Rogin, P.; Coenen, T.; Atchison, J.S.; König, P. Light emission intensities of luminescent $\mathrm{Y}_{2} \mathrm{O}_{3}$ :Eu and $\mathrm{Gd}_{2} \mathrm{O}_{3}$ :Eu particles of various sizes. Nanomaterials 2017, 7, 26. [CrossRef]

134. Bordun, O.M.; Bordun, I.O.; Yo, I. Luminescence centers in yttrium silicate and germinate. J. Appl. Spectrosc. 2017, 84, $246-254$.

135. Gu, G.; Ong, P.P.; Chen, C.; Roth, S. Synthesis and characterization of $\mathrm{Y}_{2} \mathrm{O}_{3}$ :Eu ${ }^{3+}$ thin films on silicon substrate by pulsed laser ablation. J. Phys. D Appl. Phys. 2000, 33, 1263-1266. [CrossRef]

136. Paulraj, A.; Natrajan, P.; Munnisamy, K.; Nagoor, M.K.; Nattar, K.P.; Abdlrajak, B. Photoluminescence efficiencies of nanocrystalline versus bulk $\mathrm{Y}_{2} \mathrm{O}_{3}$ : Eu phosphor-Revisited. J. Am. Ceram. Soc. 2010, 95, 1627-1633. [CrossRef]

137. Soga, K.; Tsuji, T.; Tashiro, F.; Chiba, J.; Oishi, M.; Yoshimoto, K.; Nagasaki, Y.; Kitano, K.; Hamaguchi, S. Development of NIR bioimaging systems. J. Phys. 2008, 106, 012023. [CrossRef]

138. Zako, T.; Hyodo, H.; Tisuji, K.; Tokuzen, K.; Kaneko, H.; Maedo, M. Yttrium oxide as an engineering materia. J. Nanomater. 2010, 7, 491471.

139. Giri, N.K.; Mishra, K.; Rai, B. Upconversion-based tunable white-light generation in $\mathrm{Ln}: \mathrm{Y}\left({ }_{2}\right) \mathrm{O}\left({ }_{3}\right)$ nanocrystalline phosphor $(\mathrm{Ln}=$ $\mathrm{Tm} / \mathrm{Er} / \mathrm{Yb})$. J. Fluoresc. 2011, 21, 1951-1958. [CrossRef] [PubMed]

140. Kelly, L.N.; Robert, C.D.; John, B.G.; Dhiraj, K.S. A comparative analysis of deep level emission in ZnO layers deposited by various methods. J. Appl. Phys. 2009, 105, 33102-33106.

141. Fosshein, K.; Sudho, A. Superconductivity: Physics and Applications; John Wiley \& Son's Ltd.: Hoboken, NJ, USA, 2004; ISBN 0-470-84452-3.

142. Venkatachalam, N.; Yamano, T.; Hemmer, E.; Hyodo, H.; Kishimoto, H.; Soga, K. Er ${ }^{3+}$-Doped $\mathrm{Y}_{2} \mathrm{O}_{3}$ nanophosphors for nearinfrared fluorescence bioimaging applications. J. Am. Ceram. Soc. 2013, 96, 2759-2765. [CrossRef]

143. Soga, K.; Tokuzen, K.; Tsuji, K.; Yamano, T.; Hyodo, H.; Kishimoto, H. NIR Bioimaging: Development of liposome-encapsulated, rare-earth-doped $\mathrm{Y}_{2} \mathrm{O}_{3}$ nanoparticles as fluorescent probes. Eur. J. Inorg. Chem. 2010, 2020, 2673-2677. [CrossRef] 